\title{
Seasonal variation of Microcystis aeruginosa and factors related to blooms in a deep warm monomictic lake in Mexico
}

\author{
Eloy Montero, ${ }^{1 *}$ Gabriela Vázquez, ${ }^{1}$ Margarita Caballero, ${ }^{2}$ Mario E. Favila, ${ }^{3}$ Fernando Martínez-Jerónimo ${ }^{4}$ \\ ${ }^{1}$ Red de Ecología Funcional, Instituto de Ecología, A.C. Carretera Antigua a Coatepec 351, El Haya, 91073 Xalapa, Veracruz; \\ ${ }^{2}$ Laboratorio de Paleolimnología, Instituto de Geofísica, Universidad Nacional Autónoma de México, Ciudad Universitaria, \\ Coyoacán CP 04510, CDMX.; ㄹRed de Ecoetología, Instituto de Ecología, A.C. Carretera Antigua a Coatepec 351, E1 Haya, 91073 \\ Xalapa, Veracruz; ${ }^{4}$ Laboratorio de Hidrobiología Experimental, Escuela Nacional de Ciencias Biológicas, Instituto Politécnico \\ Nacional, Prol. Carpio esq. Plan de Ayala S/N Col. Santo Tomás, CDMX 11340, México
}

\begin{abstract}
The occurrence of cyanobacterial blooms has increased globally over the last decades, with the combined effect of climate change and eutrophication as its main drivers. The seasonal dynamic of cyanobacterial blooms is a well-known phenomenon in lakes and reservoirs in temperate zones. Nevertheless, in the tropics, most studies have been performed in shallow and artificial lakes; therefore, the seasonal dynamic of cyanobacterial blooms in deep and eutrophic tropical lakes is still under research. We studied the seasonal variation of the phytoplankton community and the factors associated with Microcystis aeruginosa blooms along the water column of Lake Alberca de Tacámbaro, a warm monomictic crater lake located in Mexico, during 2018 and 2019. According to previous studies performed in 2006 and 2009-2010, this lake was mesotrophic-eutrophic, with Chlorophyta and Bacillariophyta as the dominant groups of the phytoplankton community. During 2018 and 2019, the lake was eutrophic and occasionally, hypertrophic. The dominant species was $M$. aeruginosa, forming blooms at different depths, and mostly, during autumn and winter months. These findings suggest that $M$. aeruginosa in Lake Alberca de Tacámbaro displays seasonal and spatial population dynamics. Total phosphorus, dissolved inorganic nitrogen, water temperature and photosynthetically active radiation were the environmental factors related to M. aeruginosa blooms. Our results suggest that the changes in the structure of the phytoplankton community through time, and M. aeruginosa blooms in Lake Alberca de Tacámbaro, are mainly related to changes in land use from forest to farmland in areas adjacent to the lake, which promoted its eutrophication in the last years through runoffs. Comparative studies with other deep and eutrophic lakes will allow us to gain a deeper understanding of the dynamic of cyanobacterial blooms in natural and artificial water reservoirs strongly stressed by human activities.
\end{abstract}

\section{INTRODUCTION}

The occurrence of cyanobacterial blooms in lakes and other aquatic ecosystems have increased in the last decades worldwide, becoming a problem of significant concern to water management authorities (Carey et al., 2012; O’Neil et al., 2012; Paerl and Paul, 2012; Wurtsbaugh et al., 2019). Freshwater cyanobacterial blooms

Corresponding author: eloy.montero@posgrado.ecologia.edu.mx

Key words: Cyanobacterial bloom; cyanobacterial dominance; phytoplankton community; eutrophication; tropical lake.

Edited by: Diego Fontaneto, CNR-IRSA Water Research Institute, Verbania, Italy.

Received: 9 March 2021.

Accepted: 23 April 2021.

This work is licensed under a Creative Commons Attribution NonCommercial 4.0 License (CC BY-NC 4.0).

${ }^{\circ}$ Copyright: the Author(s), 2021

Licensee PAGEPress, Italy

J. Limnol., 2021; 80(2):2013

DOI: 10.4081/jlimnol.2021.2013 are dense biomass accumulations mainly constituted by one or two species, usually evident as bright green scums on the surface (Oliver and Ganf, 2002; Huisman et al., 2018). Cyanobacterial blooms deteriorate water quality through the production of foul odor compounds, increase in turbidity, a decrease of nutrients, and oxygen depletion. When cyanotoxins are produced, cyanobacterial blooms may be harmful and toxic to aquatic biota and to the users of the water resource (Smayda, 1997; Edwin et al., 2005; Paerl and Paul, 2012; Šejnohová and Maršálek, 2012).

Significant changes in nutrient loading and the temperature regime affect phytoplankton community structure and biomass (Planas and Paquet, 2016; Caballero and Vázquez, 2020). Consequently, there is a shift in the species composition of phytoplankton communities towards dominance by cyanobacterial species (Kosten et al., 2012). Cyanobacterial blooms in lakes have been associated with high temperatures related to global warming, high water column stability, high $\mathrm{pH}$, low TN/TP ratio, and eutrophication of these aquatic ecosystems, frequently produced by discharges of treated and untreated wastewaters, as well as agriculture and farmland runoffs (Jöhnk et al., 2008; Wells et al., 2015; Planas and Paquet, 2016; Zhao et al., 2019; Wilkinson et al., 2020). Cyanobacterial blooms can be formed by filamentous 
or colonial species. The most recurrent species belong to different genera: Anabaena, Aphanizomenon, Coelosphaerium, Cylindrospermopsis, Gloeotrichia, Gomphosphaeria, Microcystis, Nodularia, Planktothrix, and Trichodesmium (Oliver and Ganf, 2002; Visser et al., 2005; Huisman et al., 2018). Microcystis aeruginosa Kützing is considered one of the most important species in cyanobacterial blooms in eutrophic lakes and reservoirs worldwide (Jacoby et al., 2000; Brunberg and Blomqvist, 2003; Ibelings et al., 2003; Vázquez et al., 2005; Jöhnk et al., 2008; Davis et al., 2009; Almanza et al., 2019; Wan et al., 2019). M. aeruginosa is a cosmopolitan freshwater cyanobacterium found as individual cells that can form large irregular colonies with a mucilaginous envelope (Reynolds et al., 1981). Cells contain cytoplasmic gas vesicles providing buoyancy and the ability to move vertically across the water column (Walsby, 1981). Some strains of M. aeruginosa can produce hepatotoxins and neurotoxins with more than 100 variants reported up to date (Lee, 2008; Puddick et al., 2015). In deep lakes, $M$. aeruginosa blooms may occur in surface waters associated with specific environmental conditions of irradiance and temperature, but they can move away from this zone within hours because of vertical migration (Reynolds et al., 1981; Visser et al., 1997; Oliver and Ganf, 2002).

Most studies on M. aeruginosa blooms have been conducted in temperate water bodies. The seasonal pattern of the population dynamics of this cyanobacterium in deep temperate lakes involves blooms in summer followed by population decline in autumn, and recovery in spring (Reynolds et al., 1981; Šejnohová and Maršálek, 2012). Nevertheless, no consensus has been reached on the behavior of this species in deep tropical lakes.

A high incidence of cyanobacterial blooms has been observed in tropical regions of Africa, America, Asia and Australia (Frias et al., 2006; Haande et al., 2007; ArzateCárdenas et al., 2010; Mowe et al., 2014; Ninio et al., 2020). In Mexico, the dominance of $M$. aeruginosa was reported for the first time in an artificial reservoir of Mexico City (Alcocer et al., 1998), and Lake Atezca, a subtropical monomictic lake (Díaz-Pardo et al., 1998). Later, blooms were reported in the Valle de Bravo reservoir (Ramírez García et al., 2002) and a eutrophic crater lake in Los Tuxtlas (Vázquez et al., 2005); in both cases, blooms were recorded in spring and summer, with a decline in biomass in surface waters during winter. The occurrence of microcystins in eutrophic reservoirs and urban lakes in Mexico has also been reported, with microcystins concentrations exceeding the WHO recommended limit $\left(1 \mu \mathrm{g} \mathrm{L}^{-1}\right)$ (Arzate-Cárdenas et al., 2010; Vasconcelos et al., 2010; Pineda-Mendoza et al., 2012); M. aeruginosa and other Microcystis species dominated the phytoplankton community of these reservoirs and urban lakes. Therefore, monitoring the presence and abundance of $M$. aeruginosa in lakes and reservoirs in Mexico from which the water is used for agricultural, recreational and human consumption purposes is crucial to avoid health risks, especially if these waterbodies are prone to eutrophication.

Lake Alberca de Tacámbaro (LAT) is a deep tropical crater lake in Mexico characterized by a circulation period in winter and stratification the rest of the year (Hernández-Morales et al., 2011; Caballero et al., 2016; Caballero and Vázquez, 2020). Local meteorological data gathered since 1988 showed a clear warming trend with consistent warmer-than-average conditions since the year 2000 (Caballero et al., 2016). Recent studies in LAT detected a $1{ }^{\circ} \mathrm{C}$ rise in the hypolimnion between 2011 and 2015 (Caballero and Vázquez, 2020). Studies performed in 2006 and 2009-2010 reported Chlorophyta and Bacillariophyta as dominant groups in the phytoplankton community, including the presence - but not dominance - of different Microcystis species (Hernández-Morales et al., 2011; Caballero et al., 2016). However, in recent years, dense green scums of biomass are common on the surface of the lake, likely related to cyanobacterial blooms. The present study assessed the seasonal variation of the phytoplankton community, particularly $M$. aeruginosa, in this lake and its relationship to different limnological factors that may be triggering cyanobacterial blooms in the water column. For this purpose, during two annual cycles (2018-2019) we i) monitored the physicochemical characteristics and nutrient concentrations in the lake; ii) determined the phytoplankton species diversity and its seasonal variations, with a particular interest in M. aeruginosa and its vertical distribution; and iii) evaluated the relationship of different environmental factors with the biovolume of $M$. aeruginosa.

\section{METHODS}

\section{Study area}

Lake Alberca de Tacámbaro (LAT) is located in the southwestern region of the Trans-Mexican Volcanic Belt in central Mexico (19 $12^{\circ}$ ' 40.56” N, 101 ${ }^{\circ} 27^{\prime} 28.59^{\prime}$ ' W, $1460 \mathrm{~m}$ asl, Fig. 1A). LAT is a warm monomictic lake with a maximum depth of $28 \mathrm{~m}$ (Hernández-Morales et al., 2011; Caballero et al., 2016; Caballero and Vázquez, 2020). The climate in this region is temperate, the warmest months span from April to June $\left(21.4 \pm 0.7^{\circ} \mathrm{C}\right)$ and the coldest from December to February $\left(17.5 \pm 0.3^{\circ} \mathrm{C}\right)$. The rainy season occurs from June to October $(239 \pm 34$ $\mathrm{mm})$, and the dry season from February to April $(8.3 \pm 5$ $\mathrm{mm})(\mathrm{SMN}, 2020)$. The main types of vegetation in the region are tropical deciduous forest and pine-oak forest (INEGI, 2016). This lake is commonly used for recre- 
ational activities, and water is extracted for irrigation purposes (Hernández-Morales et al., 2011).

\section{Evaluation of land-use changes}

Land-use changes in the surroundings of the lake were analyzed using the ArcGIS software and satellite images dating to 2007 and 2019 from Google Earth Pro ${ }^{\circledR}$. A 500 $\mathrm{m}$ buffer around the lake was created and the surfaces identified as different land-use patterns were analyzed with ArcGIS's analyst tool. Elevation data were obtained from the National Institute of Statistic and Geography of Mexico (INEGI).

\section{Sampling and laboratory analysis, chlorophyll $a$, and trophic status}

The lake was sampled at the zone of maximum depth $(28 \mathrm{~m})$ around 10:00 am (UTC -06:00) in winter (February 2018, January 2019), spring (May 2018, April 2019), summer (August 2018 and 2019) and autumn (November 2018 and 2019). The sampling method and analysis of environ-

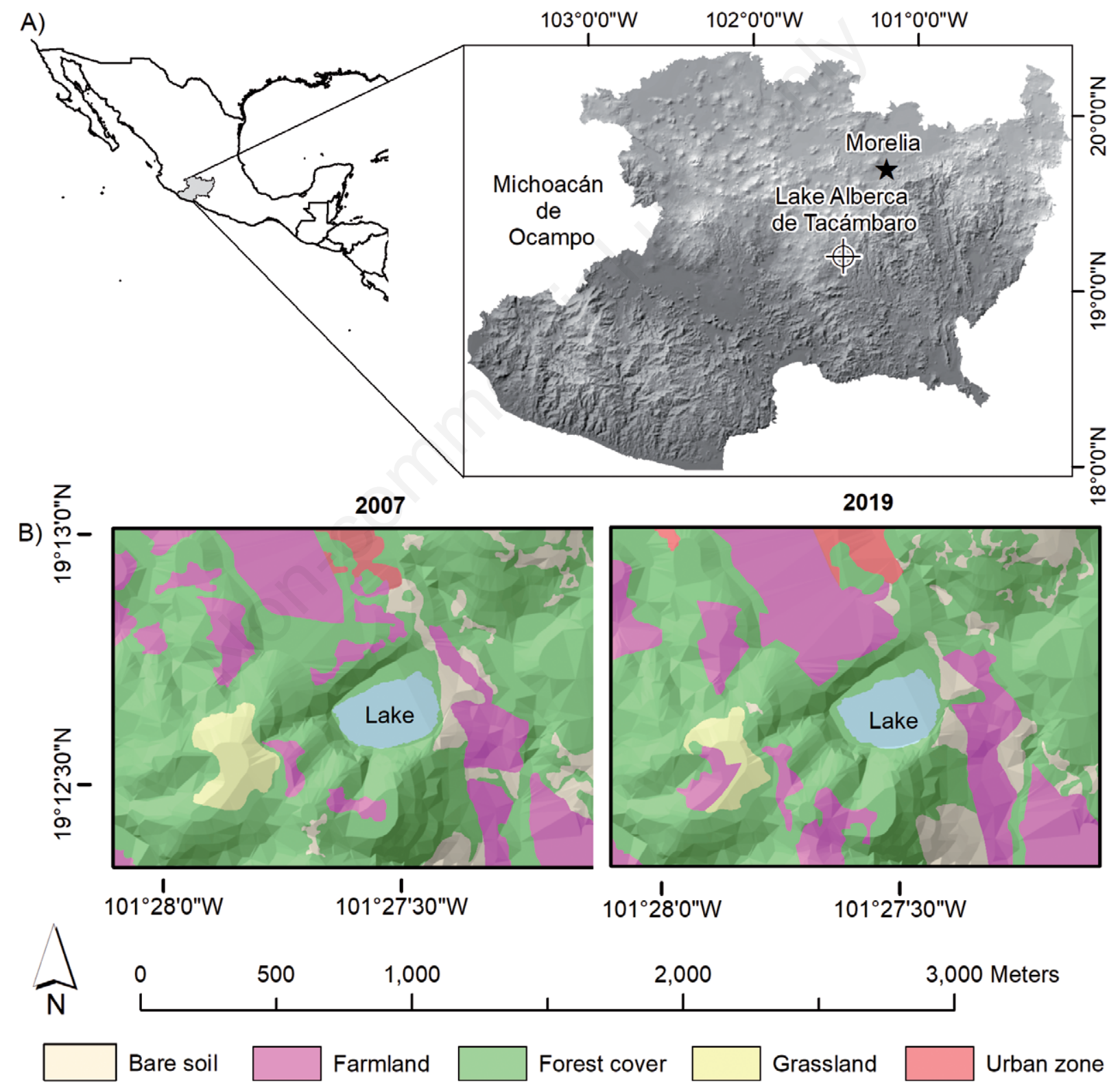

Fig. 1. A) Location of Lake Alberca de Tacámbaro. B) Land-use patterns in the area surrounding the lake during 2007 and 2019. Color intensity indicates elevation, lighter color intensity $=$ higher elevation. 
mental variables used in this study were as described in Caballero and Vázquez (2020). Profiles of temperature, dissolved oxygen (DO), conductivity and $\mathrm{pH}$ were measured in situ using a multiparametric probe $\left(\mathrm{Hydrolab}^{\circledR}\right.$, Quanta-G). Photosynthetically active radiation (PAR) profiles were measured only during 2019 using a spherical underwater quantum sensor (LI-COR $®$, LI-193). Transparency was determined with a Secchi disk and transformed to euphotic zone $\left(Z_{\text {eu }}\right)$ according to Kalff's formula (Kalff, 2002). Water samples were collected with a Van Dorn bottle at seven depths $(0,5,8,10,15,20$ and $25 \mathrm{~m})$. Water samples were used to determine ammonium $\left(\mathrm{NH}_{4}{ }^{+}\right.$, Nessler method), nitrate $\left(\mathrm{NO}_{3}{ }^{-}\right.$, brucine method), nitrite $\left(\mathrm{NO}_{2}^{-}\right.$, colorimetric method), total and reactive phosphorus (TP and $\mathrm{PO}_{4}$, persulfate digestion with the ascorbic acid method), total alkalinity $\left(\mathrm{HCO}_{3}^{-}+\mathrm{CO}_{3}{ }^{2-}\right.$, titration with phenolphthalein), chloride $\left(\mathrm{Cl}^{-}\right.$, titration with $\left.\mathrm{AgNO}_{3}\right)$, sulfate $\left(\mathrm{SO}_{4}{ }^{2-}\right.$, turbidimetric technique) and silica $\left(\mathrm{SiO}_{2}\right.$, molybdosilicate method) according to standard spectrophotometric procedures (APHA, 1998). Dissolved inorganic nitrogen (DIN) was calculated as the sum of the concentrations of $\mathrm{NH}_{4}{ }^{+}, \mathrm{NO}_{3}^{-}$, and $\mathrm{NO}_{2}^{-}$. Calcium $\left(\mathrm{Ca}^{2+}\right)$ and magnesium $\left(\mathrm{Mg}^{2+}\right)$ were measured using an atomic absorption spectrophotometer (Shimadzu® Mod. AA6501); sodium $\left(\mathrm{Na}^{+}\right)$and potassium $\left(\mathrm{K}^{+}\right)$were measured with a flame photometer (Corning ${ }^{\circledR}$ Mod. 410). Turbidity and total suspended solids (TSS) were also determined, according to APHA (1998). Water samples were kept refrigerated until analysis ( $48-72$ hours post-sampling). Samples for phosphorus analysis were stored in glass bottles.

For chlorophyll $a$ determination, water samples (500 $\mathrm{mL}$ ) were filtered through Whatman ${ }^{\circledR} \mathrm{GF} / \mathrm{C}$ filters (pore size $=1.2 \mu \mathrm{m}$ ) and then kept refrigerated in darkness for 24 hours. Chlorophyll $a$ was extracted with $90 \%$ methanol and measured spectrophotometrically; its concentration $\left(\mu \mathrm{g} \mathrm{L}^{-1}\right)$ was determined using Holden's equations (Meeks, 1974).

The trophic status of the lake was estimated by calculating the trophic state index (TSI) based on chlorophyll $a$ concentration as proposed by Carlson (1977):

$$
\operatorname{TSI}(\text { Chl } a)=10\left(6-\frac{2.04-0.68 \ln C h l a}{\ln 2}\right)(\text { eq. } 1)
$$

where Chl $a$ is the chlorophyll $a$ concentration $\left(\mu \mathrm{g} \mathrm{L}^{-1}\right)$ on the surface of the lake. The trophic status was determined according to the following scale: $\mathrm{TSI} \leq 39$, oligotrophic; 40-49, mesotrophic; 50-69, eutrophic; and 70-80, hypertrophic (Carlson, 2007).

\section{Phytoplankton biovolume}

Water samples for phytoplankton identification and quantification were collected using a Van Dorn bottle at the same depths mentioned above and fixed with formalin (4\%) and Lugol's iodine solution, respectively. Phytoplankton species were identified based on specialized literature (Bourrelly, 1968; Krammer and Lange-Bertalot, 1997, 1999, 2000; Komárek and Anagnostidis, 2007; Komárek, 2008; Moestrup and Calado, 2018). Microcystis aeruginosa Kützing was identified based on Komárek (2008). Cells were enumerated according to Utermöhl's method (Lund et al., 1958), and total cell abundance was expressed as cell $\mathrm{mL}^{-1}$. Biovolume $\left(\mu \mathrm{m}^{3} \mathrm{~mL}^{-1}\right)$ was estimated by approximation to the closest geometric shape for each species and multiplying by cell density (Hillebrand et al., 1999; Sun and Liu, 2003). In the case of $M$. aeruginosa, biovolume was estimated assuming an ellipsoid geometric shape of colonies, using the equation 2 :

$$
V=\frac{\pi}{6} \times a \times h \times b
$$

where $a$ is length and $h$ is width of each colony measured under the microscope. Colony depth $(b)$ is difficult to measure directly; therefore, it was estimated by using a linear model based on actual measurements of width and length, as proposed by Alcántara et al. (2018):

$$
b=0.7806+0.1034 \times a+0.5947 \times h(\text { eq. } 3)
$$

\section{Phytoplankton diversity}

The effective number of species (or Hill numbers) was calculated for the different orders of $q$ in Hill's formula (Jost, 2007). So, when $q=0,{ }^{0} D$ is species richness; when $q=1,{ }^{1} D$ is the exponential of Shannon's entropy and represents the effective number of common species or Shannon's diversity; when $q=2,{ }^{2} D$ is the inverse of Simpson's index diversity, which represents the effective number of dominant species or Simpson's diversity (Jost, 2007; Jost et al., 2010). Biovolume data was used to compute $q$ values. The $95 \%$ confidence intervals of $q$ values were calculated to test for significant differences between seasons. Analyses were made using the iNETX package in R Studio version 3.6.0 (Chao et al., 2014; Hsieh et al., 2016; R Core Team, 2019).

We also used dominance-diversity curves based on biovolume data (in logarithmic scale) per species as support for the analysis of community patterns (Feinsinger, 2001). The dominance-diversity graphs include only the top ten most-abundant species.

\section{Evaluation of bloom events}

The categories established by Chorus and Bartram (1999), Global Water Research Coalition and Water Quality Research Australia (2009) and Newcombe et al. (2010), were applied to determine the minimum biovolume to con- 
sider a bloom of $M$. aeruginosa. The categories for $M$. aeruginosa blooms were as follows: level $1=$ biovolume $\geq 2 \times 10^{5} \mu \mathrm{m}^{3} \mathrm{~mL}^{-1}$ and $\leq 5.9 \times 10^{5} \mu \mathrm{m}^{3} \mathrm{~mL}^{-1}$; level $2=$ biovolume $\geq 6 \times 10^{5} \mu \mathrm{m}^{3} \mathrm{~mL}^{-1}$ and $\leq 5.9 \times 10^{6} \mu \mathrm{m}^{3} \mathrm{~mL}^{-1}$; level $3=$ biovolume $\geq 6 \times 10^{6} \mu \mathrm{m}^{3} \mathrm{~mL}^{-1}$. Evaluation of blooms was limited to $15 \mathrm{~m}$ depth, because beyond this depth, the water column presents dark and anoxic conditions.

\section{Statistical analysis}

Generalized linear models with gamma distribution (positive continuous data with increasing mean-variance relationship, Dunn and Smyth, 2018) and inverse link function were used to explore the relationships between environmental variables and the biovolume of M. aeruginosa ( $\log _{10}$ transformed); significance level was 0.05 and confidence level $95 \%$. A principal component analysis (PCA) was conducted to assess the associations of environmental variables with spatial and seasonal conditions in the lake, particularly conditions presenting bloom events. Physicochemical variables were standardized by z-score transformation and then analyzed using a Pearson correlation matrix to identify those highly correlated and to discard some of them for the PCA. We tested statistical differences between the groups identified through the PCA method using the multi-response permutation procedure (MRPP) and the Bray-Curtis distance measure. These statistical analyses were made using PCORD version 6 (McCune and Grace, 2002). The other statistical analyses and graphics were performed using the statistical software R Studio version 3.6.0 (R Core Team, 2019).

\section{RESULTS}

\section{Conversion of forest to farmland in the surroundings of the lake}

The analysis of satellite images indicated that in 2007, $67.4 \%$ of the area around the lake was forest, $18.4 \%$ was farmland, $7.5 \%$ bare soil, $5.1 \%$ grassland, and $1.3 \%$ urban zone (Fig. 1B). In 2019, the forest cover represented 56.8 $\%$ of the area around the lake, farmland was $27.8 \%$, bare soil $10.4 \%$, grassland $3.1 \%$, and the urban zone $1.7 \%$. These results indicate that between 2007 and 2019, the farmland and urban areas in the lake's surroundings increased by 50 and $28 \%$, respectively; in contrast, the forest cover decreased $16 \%$. The most important land-use change was observed to the north of the volcanic cone, where a large portion of the forest became farmland (Fig. 1B).

\section{Temperature, dissolved oxygen, photosynthetically active radiation and chlorophyll $a$ profile}

In the winter of 2018 and 2019, the temperature pattern in the water column corresponded to a period of circulation, with maximum values of $19.4^{\circ} \mathrm{C}$ in 2018 and $18 .{ }^{\circ} \mathrm{C}$ in 2019 (Fig. 2A). In spring, the water column was stratified and the epilimnion reached up to $5 \mathrm{~m}$ depth in 2018 and 8 $m$ depth in 2019; in both years, the hypolimnion started at $13 \mathrm{~m}$ depth (Fig. 2A). The water column remained stratified in summer with the epilimnion at $5 \mathrm{~m}$ depth in 2018 and 8 $\mathrm{m}$ in 2019, however, in summer 2019 the hypolimnion was deeper, starting at $17 \mathrm{~m}$ depth (Fig. 2A). During autumn of both years, the epilimnion reached $13 \mathrm{~m}$ while the hypolimnion continued at $17 \mathrm{~m}$ depth (Fig. 2A). In 2018 and 2019, LAT showed a clinograde oxygen profile, which followed the thermal stratification pattern (Fig. 2B). In winter and autumn, anoxic conditions $\left(<1 \mathrm{mg} \mathrm{L}^{-1}\right)$ were observed from 14-16 m depth; meanwhile, in spring and summer, anoxic conditions were observed from the metalimnion (9$11 \mathrm{~m}$ depth).

Photosynthetically active radiation (PAR) profile varied throughout the seasons (Fig. 2C, Tab. 2). In winter 2019 , PAR reached $5 \mathrm{~m}$ depth ( $1 \%$ of surface illumination; Fig. 2C). In spring and summer 2019, PAR reached the metalimnion at $12-13 \mathrm{~m}$ depth. Finally, in autumn PAR was restricted to the epilimnion as it was undetectable beyond $10 \mathrm{~m}$ depth. The euphotic zone varied along the annual cycle between the two periods. In 2018, the deepest euphotic zone was recorded in winter (12.5 $\mathrm{m}$ ); it remained around $5 \mathrm{~m}$ deep for the rest of the year (Fig. 2C). In 2019, the lowest depth of the euphotic zone was recorded in winter $(2 \mathrm{~m})$, increasing to a maximum of $11.5 \mathrm{~m}$ in summer (Fig. 2C).

Chlorophyll $a$ profile showed the formation of a deep chlorophyll $a$ maximum (DCM) in LAT during winter, spring, and summer (Fig. 2D). In winter, DCM was found between 5 and $8 \mathrm{~m}$ depth. In spring, DCM was observed in the metalimnion in 2018 and in the hypolimnion in 2019. DCM was present in the metalimnion during summer (18.1 and $24.2 \mu \mathrm{g} \mathrm{L}^{-1}$, for 2018 and 2019, respectively). In autumn 2018 and 2019, chlorophyll $a$ concentration was constant through the water column ranging from 8 to $14.9 \mu \mathrm{g} \mathrm{L}^{-1}$.

\section{Trophic status and physical and chemical characteristics of the lake}

The trophic status of LAT varied among the seasons (Tab. 1). During 2018 the lake was eutrophic, then shifting to hypertrophic in winter 2019. In spring 2019 the lake returned to eutrophic conditions, however, TSI values increased to approach the hypertrophic category by summer and autumn 2019.

The $\mathrm{pH}$ was alkaline in the two years (7.8 and 8.1, respectively) from the surface to $10 \mathrm{~m}$, and slightly acid (6.9 and 6.6 , respectively) at the bottom of the lake $(>11 \mathrm{~m})$ (Tab. 2). In the two years, conductivity was considered low in the entire water column (147 to 235 in 2018; 125 to 217 in 2019), with a slight increase at the bottom (Tab. 

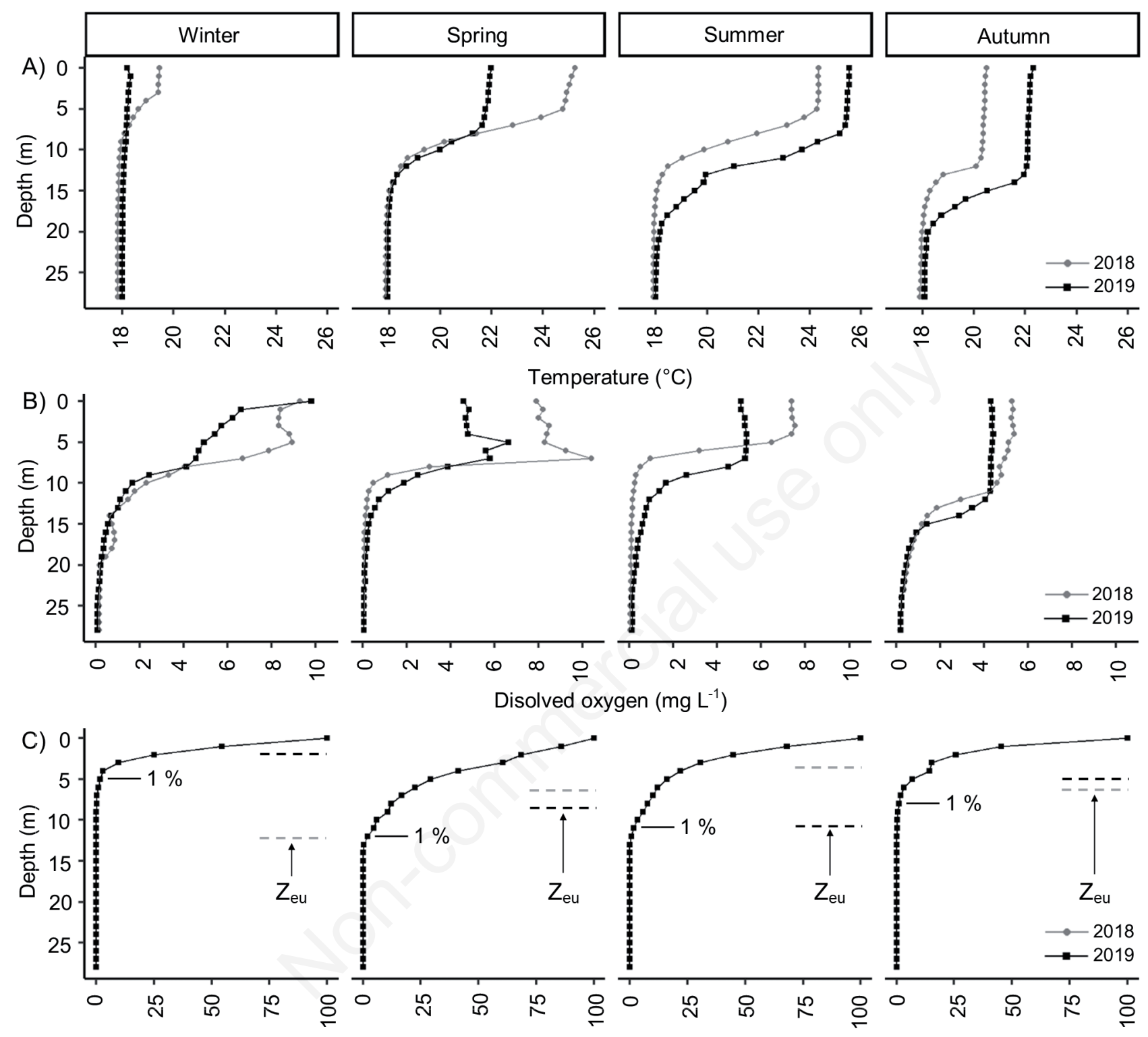

Photosynthetically active radiation (\% of surface intensity)
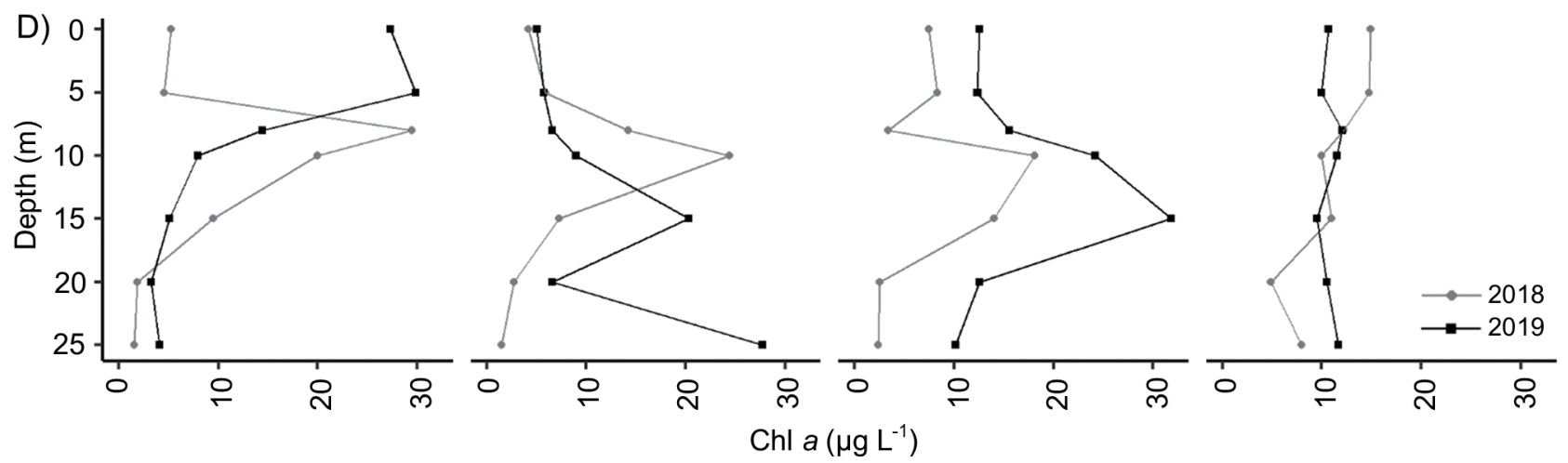

Fig. 2. Temperature (A), dissolved oxygen (B), PAR (C), and chlorophyll $a$ (D) profile in Lake Alberca de Tacámbaro during 2018 and 2019. In PAR profile (C), $1 \%$ of surface PAR intensity is marked and the horizontal dotted lines indicate the euphotic zone $\left(Z_{\text {eu }}\right)$. 
2). Dissolved inorganic nitrogen (DIN) varied from 81.2 $\mu \mathrm{M}$ at the surface to $285.6 \mu \mathrm{M}$ at the bottom of the lake in 2018 , and from $117.9 \mu \mathrm{M}$ in the surface to $229.1 \mu \mathrm{M}$ in the deepest part of the lake in 2019 (Tab. 2). A similar pattern was observed for soluble reactive phosphorus (SRP) and total phosphorus (TP), whit the highest concentrations recorded between 11 and $25 \mathrm{~m}$ depth. The DIN:SRP ratio was higher between 5 and $11 \mathrm{~m}$ depth, and the DIN:TP ratio was higher between 11 and $25 \mathrm{~m}$ depth (Tab. 2). DIN:TP ratio and silica had lower values in 2018 versus 2019 in the upper layer of the water column, but the opposite pattern was observed in the hypolimnion. The ionic composition was $\left[\mathrm{HCO}_{3}{ }^{-}+\mathrm{CO}_{3}{ }^{2-}\right]>\mathrm{Cl}^{-}>\mathrm{SO}_{4}{ }^{2-}$ and $\mathrm{Mg}^{2+}>, \mathrm{Na}^{+}>\mathrm{Ca}^{2+}>\mathrm{K}^{+}$in both years (Tab. 2). Total suspended solids (TSS) and turbidity increased with depth, being higher in 2019 versus 2018. Mean Secchi disk visibility was $4.6 \mathrm{~m}$ in 2018 and $4.1 \mathrm{~m}$ in 2019 (Tab. 2).

The PCA analysis showed different spatial and temporal patterns of the physical and chemical parameters in LAT in 2018 and 2019 (Fig. 3 A,B). The proportion explained by the first and second axes of the PCA were 40 and $13 \%$, respectively (Tab. 3). Axis 1 showed a water column depth gradient from the left (epilimnion) to the right (hypolimnion), it was positively correlated to DIN,
TP, DIN:TP ratio, $\mathrm{SiO}_{2}, \mathrm{HCO}_{3}{ }^{-}+\mathrm{CO}_{3}{ }^{2-}$ and turbidity, and negatively correlated to temperature, $\mathrm{DO}, \mathrm{SO}_{4}{ }^{2-}$ and $\mathrm{Cl}^{-}$. Axis 2 was positively correlated to $\mathrm{TP}, \mathrm{SO}_{4}^{2}, \mathrm{Cl}^{-}, \mathrm{SiO}_{2}$, and $\mathrm{Na}^{+}$, and negatively correlated to DIN:TP ratio. During 2018 and 2019, four temporal groups of physical and chemical conditions were identified (MRPP, $\mathrm{p}<0.0001$; Fig. 3 A and B, respectively). Group I was mainly com-

Tab. 1. Trophic state index and trophic status in Lake Alberca de Tacámbaro during 2018 and 2019. TSI values 0-39: oligotrophic, 40-49: mesotrophic, 50-69: eutrophic and 70-80: hypertrophic (Carlson, 2007).

\begin{tabular}{clcc}
\hline Period & & Trophic state index & Trophic status \\
\hline \multirow{2}{*}{2018} & Winter & 56 & Eutrophic \\
\hline & Spring & 54 & Eutrophic \\
\hline & Summer & 58 & Eutrophic \\
\hline & Autumn & 66 & Eutrophic \\
\hline & Winter & 71 & Hypertrophic \\
\hline & Spring & 54 & Eutrophic \\
\hline & Summer & 63 & Eutrophic \\
\hline & Autumn & 62 & Eutrophic
\end{tabular}

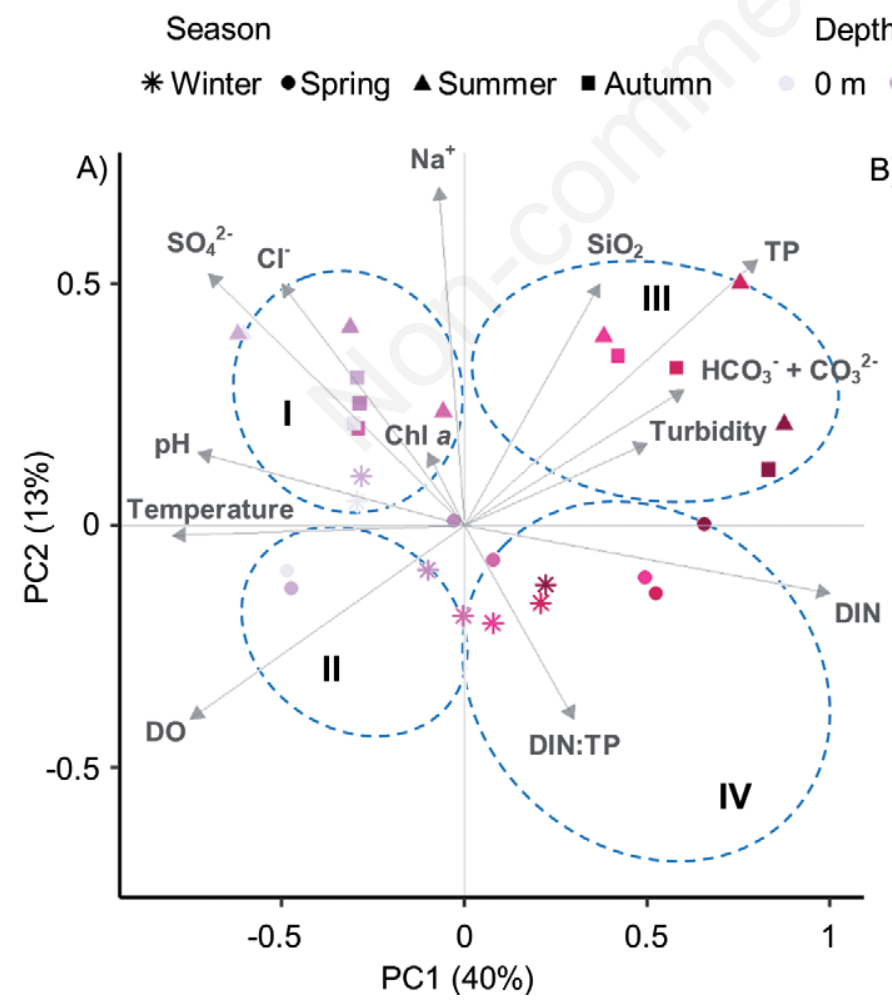

Depth

$0 \mathrm{~m} \cdot 5 \mathrm{~m} \bullet 8 \mathrm{~m} \bullet 10 \mathrm{~m} \bullet 15 \mathrm{~m} \bullet 20 \mathrm{~m} \bullet 25 \mathrm{~m}$

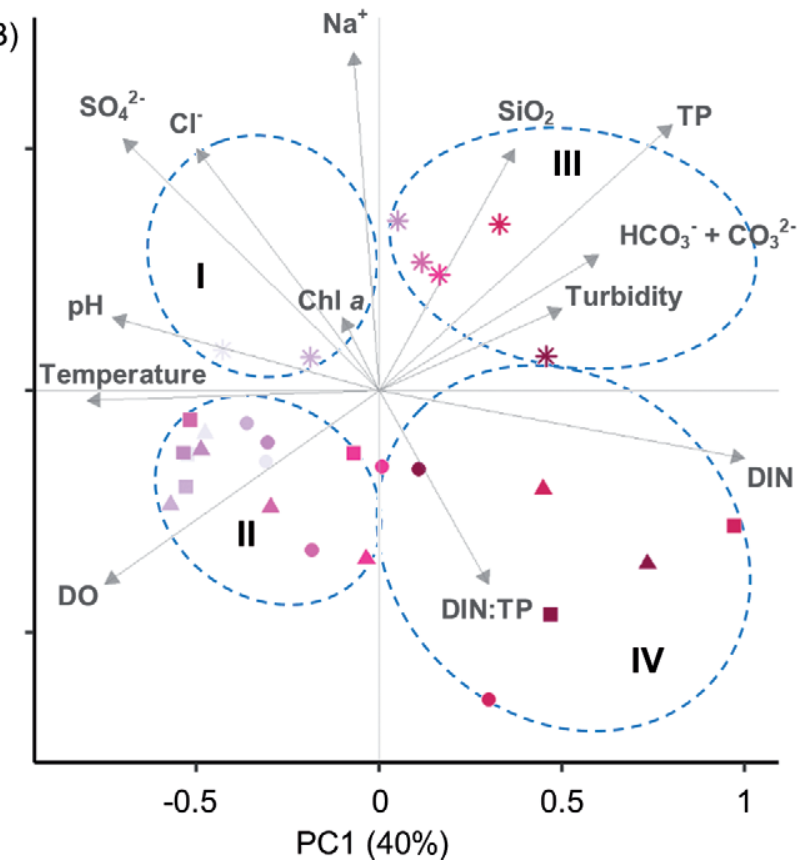

Fig. 3. PCA biplot (scaling 2) of environmental conditions in Lake Alberca de Tacámbaro. A) Samples obtained in 2018. B) Samples obtained in 2019. Symbology refers to seasons and colors to depth. Groups (circles) were significantly different based on MRPP analysis $(\mathrm{A}=0.24, \mathrm{p}<0.0001)$. 
Tab. 2. Mean, minimal and maximum annual values of biological, physical and chemical variables measured in Lake Alberca de Tacámbaro during 2018 and 2019.

\begin{tabular}{|c|c|c|c|c|c|c|c|}
\hline \multirow{3}{*}{ Variable } & \multirow[t]{3}{*}{ Year } & \multicolumn{6}{|c|}{ Depth (m) } \\
\hline & & \multicolumn{2}{|c|}{$0-5 \mathrm{~m}$} & \multicolumn{2}{|c|}{ 6-10 m } & \multicolumn{2}{|c|}{$11-27 m$} \\
\hline & & Mean & Min. - Max. & Mean & Min. - Max. & Mean & Min. - Max. \\
\hline \multirow[t]{2}{*}{ Secchi Visibility (m) } & 2018 & $2.8 \pm 4.2$ & $1.7-4.6$ & & & & \\
\hline & 2019 & $2.5 \pm 1.5$ & $0.7-4.1$ & & & & \\
\hline \multirow[t]{2}{*}{ Temperature $\left({ }^{\circ} \mathrm{C}\right)$} & 2018 & $22.2 \pm 2.5$ & $18.6-25.2$ & $20.4 \pm 2.5$ & $17.9-23.9$ & $18.1 \pm 0.4$ & $17.8-20.2$ \\
\hline & 2019 & $21.9 \pm 2.6$ & $18.2-25.5$ & $21.5 \pm 2.5$ & $18.1-25.4$ & $18.5 \pm 1.1$ & $17.9-22.9$ \\
\hline \multirow[t]{2}{*}{$\mathrm{DO}\left(\mathrm{mg} \mathrm{L}^{-1}\right)$} & 2018 & $7.3 \pm 1.3$ & $5.1-9.3$ & $3.8 \pm 2.9$ & $0.2-10.4$ & $0.5 \pm 0.7$ & $0.06-4.3$ \\
\hline & 2019 & $5.3 \pm 1.4$ & $4.3-11.3$ & $3.9 \pm 1.3$ & $1.6-5.8$ & $0.7 \pm 0.9$ & $0.07-4.3$ \\
\hline $\operatorname{PAR}\left(\mu \mathrm{mol}\right.$ photon $\left.\mathrm{m}^{2} \mathrm{~s}^{-1}\right)$ & 2019 & $242 \pm 214$ & $3-797$ & $35 \pm 40$ & $0.1-131$ & $0.9 \pm 3.8$ & $0.0-28$ \\
\hline \multirow{2}{*}{ Chl $a\left(\mu \mathrm{g} \mathrm{L}^{-1}\right)$} & 2018 & $7.8 \pm 4.2$ & $4.3-14.9$ & $15.1 \pm 8.4$ & $2.2-29.9$ & $4.8 \pm 3.3$ & $1.4-11.1$ \\
\hline & 2019 & $13.2 \pm 8.8$ & $4.7-28.1$ & $11.7 \pm 5.4$ & $6.1-23.1$ & $10.6 \pm 8$ & $2.4-26.5$ \\
\hline \multirow[t]{2}{*}{$\mathrm{pH}$} & 2018 & $8.1 \pm 0.5$ & $7.6-8.6$ & $7.6 \pm 0.3$ & $7.1-8$ & $6.9 \pm 0.5$ & $6.3-7.6$ \\
\hline & 2019 & $7.8 \pm 0.7$ & $6.6-8.6$ & $7.3 \pm 0.8$ & $6.3-8.4$ & $6.6 \pm 0.5$ & $6.1-7.8$ \\
\hline \multirow[t]{2}{*}{ Conductivity $\left(\mu \mathrm{S} \mathrm{cm}^{-1}\right)$} & 2018 & $173 \pm 23$ & $147-224$ & $174 \pm 21$ & $149-210$ & $188 \pm 22$ & $164-235$ \\
\hline & 2019 & $143 \pm 17$ & $125-179$ & $143 \pm 12$ & $126-180$ & $157 \pm 18$ & $141-217$ \\
\hline \multirow[t]{2}{*}{$\mathrm{NH}_{4}^{+}(\mu \mathrm{M})$} & 2018 & $24.3 \pm 34.8$ & $1.7-90$ & $81.7 \pm 62.8$ & $11.7-155.7$ & $275.1 \pm 125$ & $117.8-486.8$ \\
\hline & 2019 & $22.2 \pm 11.7$ & $0.7-40.3$ & $65.6 \pm 78.3$ & $5.3-202.5$ & $220.4 \pm 175.5$ & $42.1-631.8$ \\
\hline \multirow{2}{*}{$\mathrm{NO}_{3}^{-}(\mu \mathrm{M})$} & 2018 & $54.6 \pm 26.9$ & $11.5-83.5$ & $30.6 \pm 23.1$ & $0.2-66.4$ & $9.9 \pm 7.5$ & $2.5-30.3$ \\
\hline & 2019 & $94.6 \pm 90.3$ & $7.1-239.0$ & $85.5 \pm 68.4$ & $9.4-219.7$ & $8.6 \pm 4.2$ & $6.5-21.4$ \\
\hline \multirow{2}{*}{$\mathrm{NO}_{2}^{-}(\mu \mathrm{M})$} & 2018 & $2.2 \pm 2.7$ & $0-5.7$ & $2.8 \pm 2.9$ & $0-5.7$ & $0.5 \pm 0.6$ & $0-2.1$ \\
\hline & 2019 & $1.1 \pm 1.0$ & $0-3.4$ & $1.1 \pm 0.6$ & $0.1-2$ & $0.1 \pm 0.1$ & $0-0.4$ \\
\hline \multirow[t]{2}{*}{$\overline{\mathrm{DIN}}(\mu \mathrm{M})$} & 2018 & $81.2 \pm 53.1$ & $18.9-161.9$ & $119.4 \pm 47.5$ & $46.6-185.0$ & $285.6 \pm 122.9$ & $149.4-495.9$ \\
\hline & 2019 & $117.9 \pm 87.4$ & $48.6-254.0$ & $156.2 \pm 70.1$ & $56.2-247.1$ & $229.1 \pm 174.5$ & $49.3-638.9$ \\
\hline \multirow[t]{2}{*}{$\mathrm{SRP}(\mu \mathrm{M})$} & 2018 & $0.5 \pm 0.3$ & $0.3-1.2$ & $0.6 \pm 0.4$ & $0.2-1.4$ & $3.3 \pm 2.9$ & $0.2-9.1$ \\
\hline & 2019 & $4.9 \pm 8.2$ & $0.3-18.8$ & $0.7 \pm 0.6$ & $0.3-2.0$ & $7.8 \pm 9.1$ & $0.4-32.9$ \\
\hline \multirow[t]{2}{*}{$\mathrm{TP}(\mu \mathrm{M})$} & 2018 & $4.1 \pm 1.9$ & $2.1-7.9$ & $4.5 \pm 2.1$ & $2.3-8.8$ & $10.1 \pm 4.3$ & $3.4-16.1$ \\
\hline & 2019 & $3.9 \pm 1.8$ & $1.3-6.8$ & $4.1 \pm 2.1$ & $1.1-7.2$ & $13.7 \pm 7.2$ & $4.8-26.7$ \\
\hline \multirow[t]{2}{*}{ DIN:SRP ratio } & 2018 & $139 \pm 65$ & $58-248$ & $245 \pm 172$ & $101-642$ & $192 \pm 209$ & $40-739$ \\
\hline & 2019 & $165 \pm 122$ & $2-349$ & $300 \pm 183$ & $73-601$ & $76 \pm 65$ & $2-191$ \\
\hline DIN:TP ratio & 2018 & $19 \pm 8$ & $8-30$ & $26 \pm 6$ & $16-39$ & $33 \pm 18$ & $15-79$ \\
\hline & 2019 & $34 \pm 21$ & $10-69$ & $41 \pm 17$ & $20-64$ & $18 \pm 12$ & $2-47$ \\
\hline $\mathrm{SiO}_{2}(\mu \mathrm{M})$ & 2018 & $822 \pm 53$ & $747-887$ & $862 \pm 45$ & $756-898$ & $911 \pm 23$ & $884-948$ \\
\hline & 2019 & $885 \pm 9$ & $873-898$ & $870 \pm 10$ & $861-884$ & $866 \pm 10$ & $856-886$ \\
\hline $\mathrm{HCO}_{3}{ }^{-}+\mathrm{CO}_{3}{ }^{2-}\left(\mathrm{meq} \mathrm{L}{ }^{-1}\right)$ & 2018 & $1.5 \pm 0.1$ & $1.4-1.6$ & $1.5 \pm 0.1$ & $1.5-1.6$ & $1.7 \pm 0.1$ & $1.6-1.9$ \\
\hline & 2019 & $1.5 \pm 0.1$ & $1.4-1.6$ & $1.6 \pm 0.1$ & $1.5-1.6$ & $1.7 \pm 0.1$ & $1.6-1.9$ \\
\hline$\left.\overline{\mathrm{Cl}^{-}(\text {meq L }}{ }^{-1}\right)$ & 2018 & $0.2 \pm 0.0$ & $0.1-0.3$ & $0.2 \pm 0.0$ & $0.1-0.3$ & $0.1 \pm 0.0$ & $0.1-0.2$ \\
\hline & 2019 & $0.3 \pm 0.1$ & $0.2-0.4$ & $0.3 \pm 0.1$ & $0.2-0.4$ & $0.2 \pm 0.1$ & $0.1-0.3$ \\
\hline $\mathrm{SO}_{4}^{2-}\left(\right.$ meq L $\left.{ }^{-1}\right)$ & 2018 & $0.1 \pm 0.0$ & $0.0-0.1$ & $0.1 \pm 0.0$ & $0.0-0.1$ & $0.0 \pm 0.0$ & $0.0-0.0$ \\
\hline & 2019 & $0.1 \pm 0.0$ & $0.0-0.1$ & $0.1 \pm 0.0$ & $0.1-0.1$ & $0.1 \pm 0.0$ & $0.0-0.1$ \\
\hline $\mathrm{Ca}^{2+}\left(\mathrm{meq} \mathrm{L}^{-1}\right)$ & 2018 & $0.3 \pm 0.1$ & $0.1-0.5$ & $0.3 \pm 0.1$ & $0.2-0.5$ & $0.3 \pm 0.1$ & $0.1-0.5$ \\
\hline & 2019 & $0.1 \pm 0.0$ & $0.1-0.2$ & $0.1 \pm 0.0$ & $0.1-0.2$ & $0.1 \pm 0.0$ & $0.1-0.2$ \\
\hline $\mathrm{Mg}^{2+}\left(\right.$ meq L $\left.{ }^{-1}\right)$ & 2018 & $0.9 \pm 0.0$ & $0.9-0.9$ & $0.9 \pm 0.0$ & $0.9-1$ & $1 \pm 0.0$ & $0.9-1$ \\
\hline & 2019 & $1 \pm 0.0$ & $0.8-1$ & $1 \pm 0.1$ & $0.8-1.1$ & $0.9 \pm 0.1$ & $0.8-1$ \\
\hline $\mathrm{Na}^{+}\left(\right.$meq L L $\left.{ }^{-1}\right)$ & 2018 & $0.5 \pm 0.1$ & $0.4-0.6$ & $0.5 \pm 0.1$ & $0.4-0.6$ & $0.5 \pm 0.1$ & $0.4-0.6$ \\
\hline & 2019 & $0.5 \pm 0.1$ & $0.4-0.6$ & $0.5 \pm 0.1$ & $0.4-0.7$ & $0.6 \pm 2$ & $0.4-1$ \\
\hline $\mathrm{K}^{+}\left(\mathrm{meq} \mathrm{L}^{-1}\right)$ & 2018 & $0.05 \pm 0.00$ & $0.04-0.05$ & $0.05 \pm 0.00$ & $0.05-0.06$ & $0.05 \pm 0.00$ & $0.05-0.06$ \\
\hline & 2019 & $0.05 \pm 0.00$ & $0.04-0.06$ & $0.05 \pm 0.01$ & $0.04-0.06$ & $0.05 \pm 0.00$ & $0.04-0.06$ \\
\hline $\mathrm{TSS}\left(\mathrm{mg} \mathrm{L}^{-1}\right)$ & 2018 & $4.8 \pm 2.7$ & $1.8-7.8$ & $4.9 \pm 1.4$ & $3.1-7.1$ & $3.3 \pm 2$ & $1.6-5.7$ \\
\hline & 2019 & $5 \pm 1.8$ & $2-7.2$ & $4.2 \pm 1.6$ & $1.9-6.3$ & $5.8 \pm 1$ & $4.2-7.3$ \\
\hline Turbidity (NTU) & 2018 & $3.2 \pm 1.2$ & $2-5$ & $3.1 \pm 0.9$ & $2-4.5$ & $7.9 \pm 6.5$ & $1-21$ \\
\hline & 2019 & $3.8 \pm 2.6$ & $2-10$ & $4.2 \pm 2.1$ & $2.5-9$ & $12.2 \pm 4.5$ & $6-21.5$ \\
\hline
\end{tabular}

Data for 2018 and 2019, are presented as annual arithmetic average for samples from $0-5 \mathrm{~m}$ depth $(n=8), 6-10 \mathrm{~m}$ depth $(n=8)$ and $11-27 \mathrm{~m} \mathrm{depth}$ $(n=12)$. Except for temperature, DO, PAR and conductivity, which were measured each meter depth, number of data is different: $0-5 \mathrm{~m}, n=24 ; 6-$ $10 m, n=20 ; 11-27 m, n=72$. 
prised of samples from the epilimnion in 2018, and surface samples from winter 2019; this group was associated with high temperature, $\mathrm{pH}, \mathrm{SO}_{4}{ }^{2-}$ and $\mathrm{Cl}^{-}$concentrations (Fig. 3 A,B). Group II included most of the samples from $8-15 \mathrm{~m}$ depth of both years; samples from this group were associated with high temperatures and high DO concentrations. Group III was associated with the highest $\mathrm{SiO}_{2}, \mathrm{TP}, \mathrm{HCO}_{3}{ }^{-}+\mathrm{CO}_{3}{ }^{2-}$ and turbidity concentrations and constituted by samples from the hypolimnion (20-25 m) in summer and autumn 2018, and winter 2019 (from 8$25 \mathrm{~m}$ depth). Finally, group IV included samples from the deeper layer of the water column (15-25 m), which corresponded to winter and spring 2018, and spring, summer, and autumn 2019; such group was associated with the highest DIN concentrations and DIN:TP ratio.

\section{Phytoplankton community}

A total of 112 phytoplankton taxa were recorded in this study (Supplementary material). In 2018, the highest species richness $\left({ }^{0} D\right)$ was observed in spring and autumn; Shannon's diversity $\left({ }^{1} D\right)$ ranged from 1.1 to 1.6 species and Simpson's diversity $\left({ }^{2} D\right)$ was always close to one, indicating that $M$. aeruginosa was the only dominant species in LAT throughout this year (Tab. 4). In 2019, the highest species richness $\left({ }^{\circ} D\right)$ was observed in winter and spring. Shannon's and Simpson's diversities were highest in spring; $M$. aeruginosa continued being the only dominant species for the rest of the year.

Lake Alberca de Tacámbaro showed a trend in the seasonal and spatial distribution of the phytoplankton community (Fig. 4). In winter 2018, phytoplankton biovolume was dominated by Cyanobacteria, mostly $M$. aeruginosa (98\%), which was distributed in the entire water column. In this season, the Bacillariophyceae was another dominant group, distributed mostly between 10 to $15 \mathrm{~m}$ depth (Fig. 4A). In spring 2018, Chlorophyceae and Dinophyceae represented about $80 \%$ of biovolume between 0 and $5 \mathrm{~m}$ depth, while it was mostly integrated by $M$. aeruginosa from $8 \mathrm{~m}$ depth to the bottom (Fig. 4B). In summer 2018, the phytoplankton community was composed of a diverse algae assemblage from 0 to $15 \mathrm{~m}$ depth, mostly by Bacillariophyceae and Dinophyceae; from 20 $\mathrm{m}$ depth to the bottom, M. aeruginosa accounted for 99 $\%$ of the biovolume (Fig. 4C). In autumn 2018, M. aeruginosa was the dominant species along the water column; other algae classes were also observed but they only represented 2 to $5 \%$ of the community (Fig. 4D).

In winter 2019, Chlorophyceae and Cryptophyceae constituted $60-70 \%$ of phytoplankton biovolume at the top $5 \mathrm{~m}$ of the water column; $M$. aeruginosa was the predominant species from 8 to $25 \mathrm{~m}$ depth, with also a significant presence of Bacillariophyceae at 20-25 m depth (Fig. 4E). In spring 2019, Chlorophyceae and Dinophyceae were the dominant algae from 0 to $10 \mathrm{~m}$ depth

Tab. 3. Eigenvalues and percent of the total variance accounted by the first two axis, and correlations between variables and axes $(\mathrm{n}=56)$.

\begin{tabular}{lcc} 
& Axis 1 & Axis 2 \\
Eigenvalues & 5.32 & 1.68 \\
\hline Percentage explained & 40.98 & 12.97 \\
\hline Cum. percentage & 40.98 & 53.95 \\
\hline Eigenvectors & & \\
\hline Chl $a$ & -0.36 & 0.28 \\
\hline Temperature & -1.01 & -0.01 \\
\hline Dissolved oxygen & -1.04 & -0.21 \\
\hline $\mathrm{pH}$ & -0.95 & 0.10 \\
\hline $\mathrm{DIN}$ & 1.10 & -0.15 \\
\hline $\mathrm{TP}$ & -1.06 & 0.65 \\
\hline $\mathrm{DIN}^{\mathrm{TP}}$ ratio & 0.64 & -0.62 \\
\hline $\mathrm{SO}_{4}^{2-}$ & -0.98 & 0.62 \\
\hline $\mathrm{Cl}^{-}$ & -0.72 & 0.45 \\
\hline $\mathrm{SiO}_{2}$ & 0.62 & 0.52 \\
\hline $\mathrm{HCO}_{3}{ }^{-}+\mathrm{CO}_{3}{ }^{2}$ & 0.78 & 0.33 \\
\hline $\mathrm{Na}^{+}$ & -0.05 & 1.02 \\
\hline $\mathrm{Turbidity}^{-}$ & 0.68 & 0.10 \\
\hline
\end{tabular}

Tab. 4. Diversity measurements in Lake Alberca de Tacámbaro during 2018 and 2019. Superscript letters in $D$ indicate significant differences calculated based on confidence intervals $( \pm) .{ }^{0} D=$ species richness, ${ }^{1} D=$ Shannon's diversity, ${ }^{2} D=$ Simpson's diversity.

\begin{tabular}{clcccc}
\hline \hline Period & & ${ }^{0} D$ & ${ }^{1} D$ & & Coverage $(\%)$ \\
\hline & Winter & $47 \pm 4^{\mathrm{bc}}$ & 1.6 & 1.2 & 99 \\
\hline & Spring & $61 \pm 7^{\mathrm{a}}$ & 1.3 & 1.1 & 99 \\
\hline & Summer & $43 \pm 1^{\mathrm{c}}$ & 1.6 & 1.1 & 99 \\
\hline & Autumn & $56 \pm 9^{\mathrm{ab}}$ & 1.1 & 1 & 99 \\
\hline & Winter & $63 \pm 10^{\mathrm{a}}$ & 1.4 & 1.1 & 99 \\
\hline & Spring & $69 \pm 14^{\mathrm{a}}$ & 3.9 & 2.8 & 99 \\
\hline
\end{tabular}


representing about $95 \%$ of biovolume, while $M$. aeruginosa was dominant in association with Bacillariophyceae species beyond $20 \mathrm{~m}$ depth (Fig. 4F). In summer 2019, Chlorophyceae was the main component of biovolume from 0 to $15 \mathrm{~m}$ depth (80-90\%), while $M$. aeruginosa again made $99 \%$ of the community from $15 \mathrm{~m}$ depth to the bottom (Fig. 4G). Finally, in autumn 2019, M. aeruginosa accounted for 95-98\% of biovolume, while other algae classes represented again 2 to $5 \%$ of the community (Fig. 4H).

The dominance-diversity curves showed that the difference in biovolume from the most abundant species to the next changed over time (Fig. 5). The dominant species in all sampling seasons was $M$. aeruginosa, and the difference relative to the second most-abundant species was very large in spring, summer and autumn 2018, and in winter and autumn 2019. In winter 2018 and summer 2019, the difference versus the second most-abundant species was lower. In spring 2019, there were three dominant species (Aulacoseira granulata (Ehrenberg) Simonsen, Oocystis marssonii Lemmermann, and M. aeruginosa), and the differences in biovolume were the lowest in the two years, indicating a more diverse community.

\section{Biovolume and blooms of M. aeruginosa}

Microcystis blooms were observed in the samplings performed in winter, spring and autumn, but they occurred at different depths (Fig. 6). In winter 2018, level-1 and 2 blooms were identified from the surface to $10 \mathrm{~m}$ depth; maximum biovolume at $20-25 \mathrm{~m}$ depth was $7.7 \times 10^{6} \mu \mathrm{m}^{3}$ $\mathrm{mL}^{-1}$ (Fig. 6A). In spring 2018, level 1 and 2 blooms were observed between 8 and $10 \mathrm{~m}$ depth (Fig. 6B); biovolume at $25 \mathrm{~m}$ depth was $6.9 \times 10^{6} \mu \mathrm{m}^{3} \mathrm{~mL}^{-1}$. Blooms were not observed in summer 2018, and biovolume at $20-25 \mathrm{~m}$ depth ranged from 5.9 to $6.4 \times 10^{6} \mu \mathrm{m}^{3} \mathrm{~mL}^{-1}$ (Fig. 6C). In autumn 2018, level-1, 2, and 3 blooms were observed from the surface to $15 \mathrm{~m}$ depth; maximum biovolume was $2 \times 10^{7} \mu \mathrm{m}^{3} \mathrm{~mL}^{-1}$ recorded at $25 \mathrm{~m}$ depth (Fig. 6D). In winter 2019, level-2 and 3 blooms were identified between 8 and $15 \mathrm{~m}$ depth (Fig. 6E). In spring 2019, a level-1 was recorded at $15 \mathrm{~m}$ depth (spring) but maximum biovolume was registered at $20 \mathrm{~m}$ depth (Fig. 6 F,G). In summer 2019 , there was no presence of blooms; however, a biovolume of $3.3 \times 10^{7} \mu \mathrm{m}^{3} \mathrm{~mL}^{-1}$ was registered at $25 \mathrm{~m}$ depth (Fig. 6G). Similar to 2018, in autumn 2019, level-2 and 3 blooms were recorded from the surface to $15 \mathrm{~m}$ depth with maximum biovolume at $25 \mathrm{~m}$ depth (Fig. $6 \mathrm{H}$ ).

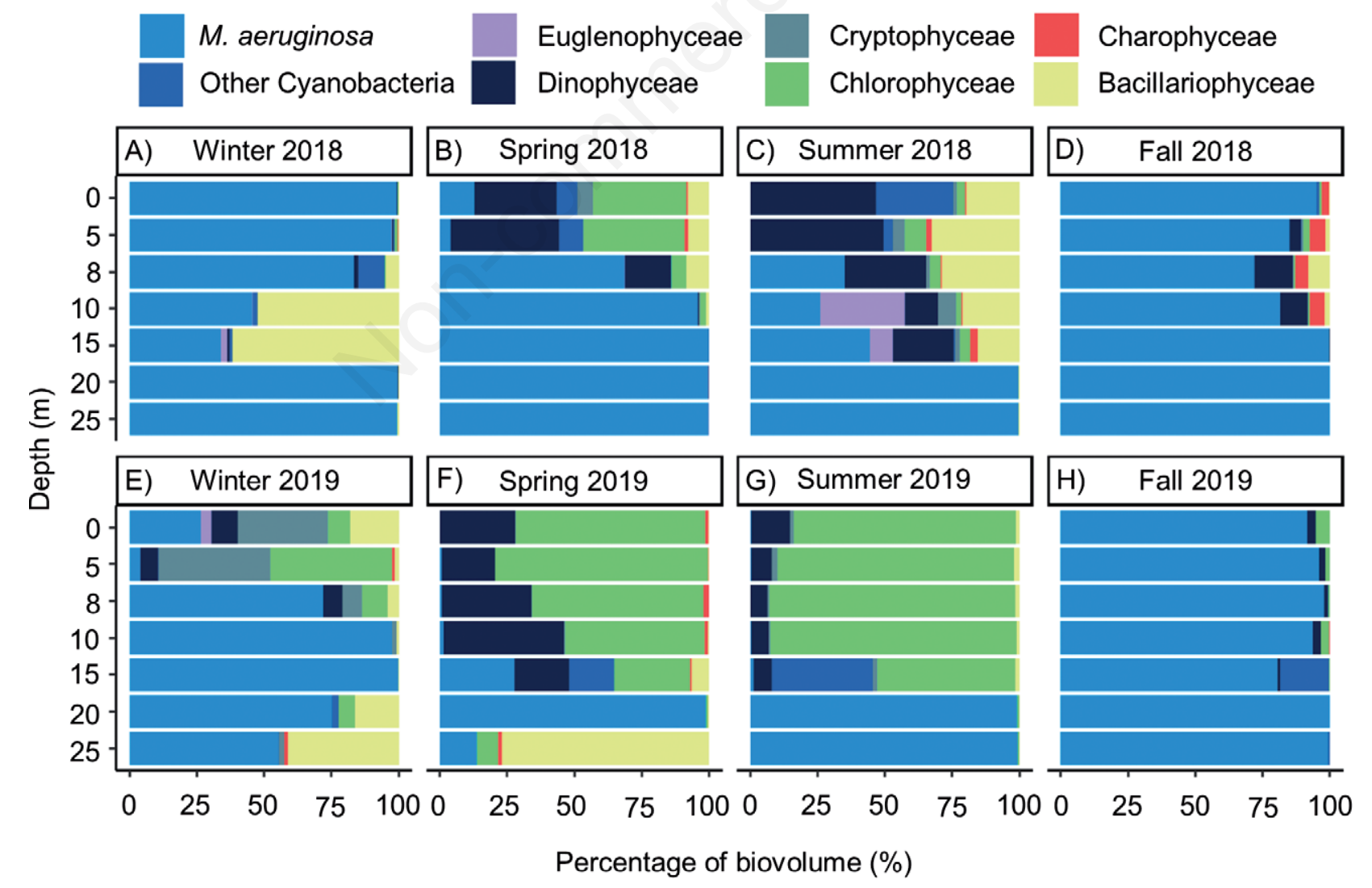

Fig. 4. Percentage of the biovolume of different algae classes and $M$. aeruginosa recorded at $0,5,8,10,15,20$ and $25 \mathrm{~m}$ depth in Lake Alberca de Tacámbaro during 2018 and 2019. 
GLMs indicated that the biovolume of $M$. aeruginos was significantly and positively related to DIN (Fig. 7A, $\mathrm{p}=0.001)$, TP (Fig. 7B, $\mathrm{p}=0.001)$ and $\mathrm{HCO}_{3}{ }^{-}+\mathrm{CO}_{3}{ }^{2-}$ (Fig. $7 \mathrm{C}, \mathrm{p}=0.002$ ). In contrast, $M$. aeruginosa biovolume was significantly and negatively related to temperature (Fig. 7D, p <0.001), PAR (Fig. 7E, p=0.04) and pH (Fig. 7F, $\mathrm{p}=0.02)$. Other variables such as $\operatorname{SRP}(\mathrm{p}=0.98), \mathrm{DIN}: \mathrm{SRP}$ ratio $(p=0.87)$, DIN:TP ratio $(p=0.17), \mathrm{SiO}_{2}(\mathrm{p}=0.07), \mathrm{Na}^{+}$ $(p=0.49)$ and chlorophyll $a$ concentration $(p=0.68)$ showed no significant relationships with $M$. aeruginosa biovolume.

\section{DISCUSSION}

Lake Alberca de Tacámbaro showed a warm monomictic stratification pattern throughout the study period. This behavior is common to deep lakes from tropical and warm temperate regions, where the winter circulation period is usually driven by wind in conjunction with a slight decrease in atmospheric temperature (Wetzel, 2001). This study confirms the recurrent formation of a deep chlorophyll $a$ maximum (DCM) in this lake reported by Caballero and Vázquez (2020), which forms during the early stages of the water column stratification processes (spring) and extends over the stratification months (summer and autumn). The composition of the phytoplankton community observed in our study suggests that the DCM in LAT is constituted mainly by Chlorophyceae and Dinophyceae species in spring, by Chlorophyceae, Dinophyceae, and $M$. aeruginosa in summer and autumn.

During 2018 and 2019, we found marked changes in the trophic status and structure of the phytoplankton community in the lake, compared to reports for previous years. In 2006, LAT was classified as mesotrophic lake, with Bacillariophyceae and Chlorophyceae as the dominant groups (Hernández-Morales et al., 2011) (Tab. 5). A few years later (2009-2010), the lake was described as eutrophic with a significant increase in DIN concentration in the surface layer; Chlorophyceae species continued dominating the phytoplankton community, and cyanobacterial dominance was not observed (Caballero et al., 2016) (Tab. 5). Within this study (2018 and 2019), TP and DIN concentrations increased considerably compared to values reported for 2009 and 2010. Currently, this lake shows conditions shifting from eutrophic to hypertrophic, and M. aeruginosa is the dominant species (Tab. 5).

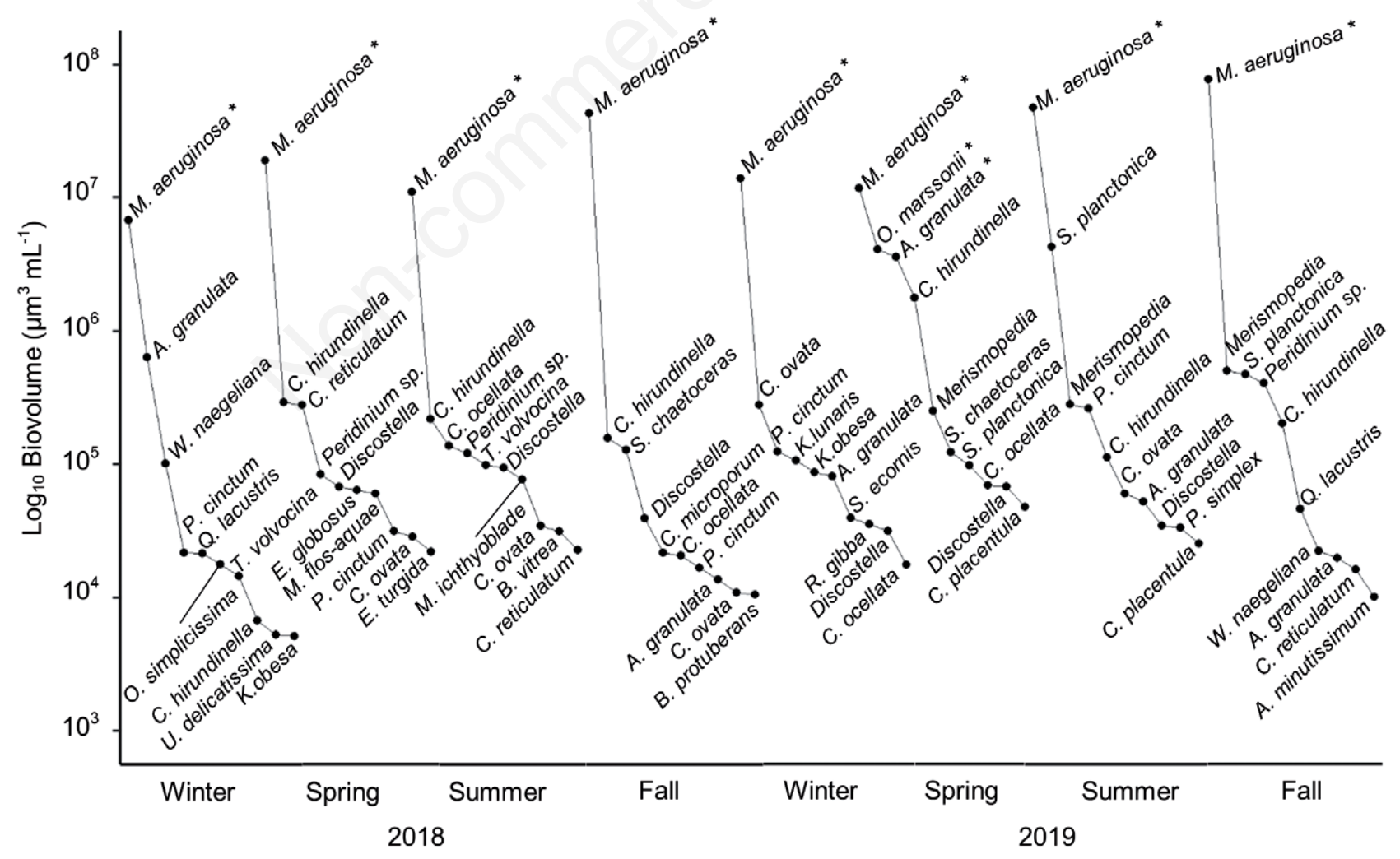

Fig. 5. Dominance-diversity curves showing the top ten most-abundant algae species in Lake Alberca de Tacámbaro during 2018 and 2019. Discostella is D. pseudostelligera. Merismopedia involves M. duplex, M. punctata and M. tenuissima. Asterisks indicate the dominant species. 


\section{Phytoplankton community}

In LAT, three seasonal trends were observed in the phytoplankton community: the winter dominance of $M$. aeruginosa accompanied by lower proportions of Bacillariophyceae and Chlorophyceae; the high algae di- versity in the epilimnion and metalimnion with Chlorophyceae and Dinophyceae as the dominant groups during the warmest seasons (spring and summer); and finally, the complete dominance of $M$. aeruginosa in autumn. These seasonal trends of the phytoplankton community showed that thermal stratification plays a crucial role in the phyto-

Tab. 5. TP and DIN concentrations and dominant algae observed in Lake Alberca de Tacámbaro during 2006, 2009, 2010,2018 and 2019.

\begin{tabular}{|c|c|c|c|c|c|c|}
\hline Year & Depth (m) & $\mathrm{TP}(\mu \mathrm{M})$ & $\operatorname{DIN}(\mu \mathrm{M})$ & Trophic status & Dominant algae & Reference \\
\hline 2006 & 0 & 1.7 & 5.8 & Mesotrophic & $\begin{array}{l}\text { Bacillariophyceae (Winter) and } \\
\text { Chlorophyceae (rest of the year) }\end{array}$ & Hernández-Morales et al., 2011 \\
\hline 2009 to 2010 & $\begin{array}{c}0-5 \\
6-10 \\
11-25\end{array}$ & $\begin{array}{l}1.4 \pm 1.0 \\
1.2 \pm 0.6 \\
3.4 \pm 3.4\end{array}$ & $\begin{array}{c}45 \pm 50 \\
70 \pm 56 \\
170 \pm 67\end{array}$ & Eutrophic & Chlorophyceae (the full year) & Caballero et al., 2016 \\
\hline 2018 & $\begin{array}{c}0-5 \\
6-10 \\
11-27\end{array}$ & $\begin{array}{c}4.1 \pm 1.9 \\
4.5 \pm 2.1 \\
10.1 \pm 4.3\end{array}$ & $\begin{array}{c}81 \pm 50 \\
12048 \\
285 \pm 122\end{array}$ & Eutrophic & M. aeruginosa (the full year) & Present work \\
\hline 2019 & $\begin{array}{c}0-5 \\
6-10 \\
11-27\end{array}$ & $\begin{array}{c}3.9 \pm 1.8 \\
4.1 \pm 2.0 \\
13.7 \pm 7.2\end{array}$ & $\begin{array}{c}117 \pm 87 \\
156 \pm 70 \\
229 \pm 174\end{array}$ & Eutrophic-Hypertrophic & $\begin{array}{l}\text { M. aeruginosa (the full year) and } \\
\text { Chlorophyta (Spring) }\end{array}$ & \\
\hline
\end{tabular}

Data for 2018 and 2019 are presented as annual arithmetic average for samples from $0-5 \mathrm{~m}$ depth $(n=8), 6-10 \mathrm{~m}$ depth $(n=8)$ and $11-27 \mathrm{~m}$ depth $(n=12)$.
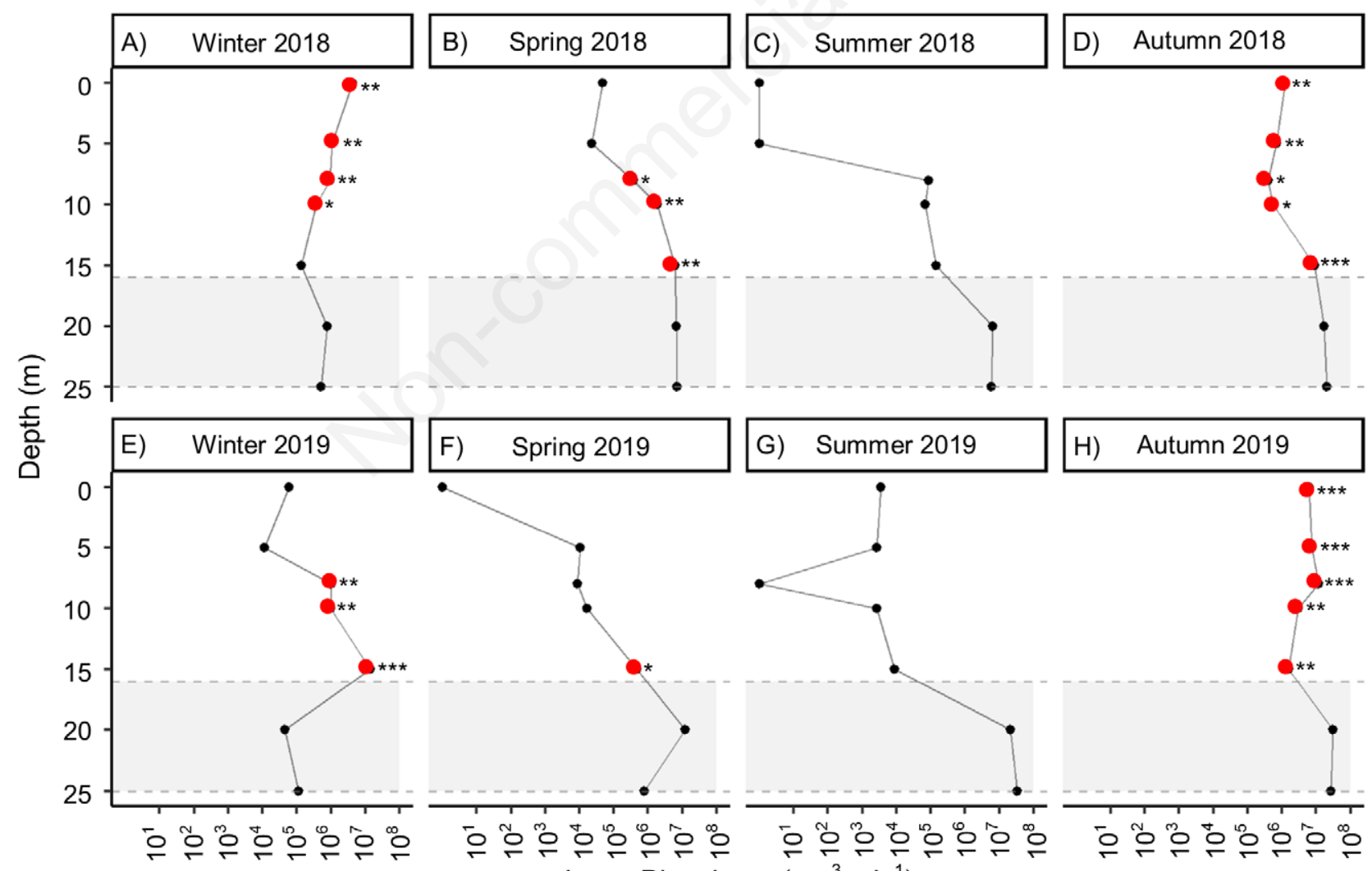

$\log _{10}$ Biovolume $\left(\mu \mathrm{m}^{3} \mathrm{~mL}^{-1}\right)$

Fig. 6. Biovolume of $M$. aeruginosa at 0, 5, 8, 10, 15, 20 and $25 \mathrm{~m}$ depth in Lake Alberca de Tacámbaro during 2018 and 2019 . Red circles indicate Microcystis blooms. Asterisks denote bloom intensity: *level 1 (biovolume $\geq 2 \times 10^{5} \mu \mathrm{m}^{3} \mathrm{~mL}^{-1}$ and $\leq 5.9 \times 10^{5} \mu \mathrm{m}^{3} \mathrm{~mL}^{-1}$ ); **level 2 (biovolume $\geq 6 \times 10^{5} \mu \mathrm{m}^{3} \mathrm{~mL}^{-1}$ and $\leq 5.9 \times 10^{6} \mu \mathrm{m}^{3} \mathrm{~mL}^{-1}$ ); $* * *$ level 3 (biovolume $\geq 6 \times 10^{6} \mu \mathrm{m}^{3} \mathrm{~mL}^{-1}$ ). Shaded areas represent the zone of the water column where dark and anoxic conditions were registered. 
plankton dynamics of deep tropical lakes since this process influences the distribution of dissolved oxygen, as well as the nutrient and light availability for algae, among others (Huisman et al., 2004; Winder and Hunter, 2008).

In 2018 and 2019, M. aeruginosa was the dominant species in LAT, and only in spring 2019, two species were co-dominant with $M$. aeruginosa, one Chlorophyceae $(O$. marssonii) and one Bacillariophyceae (A. granulata); such species were associated with conditions of high tem- perature and DO concentration. In previous years, Chlorophyceae and Bacillariophyceae were the dominant groups in LAT, and C. reticulatum, Botryococcus sp., Sphaerocystis sp., T. minimum, A. minutissimum, C. ocellata and U. ulna, were the most abundant species (HernándezMorales et al., 2011; Caballero et al., 2016). In our study, these species were always recorded at lower abundances relative to $M$. aeruginosa. This shift in the composition of the phytoplankton community towards cyanobacterial
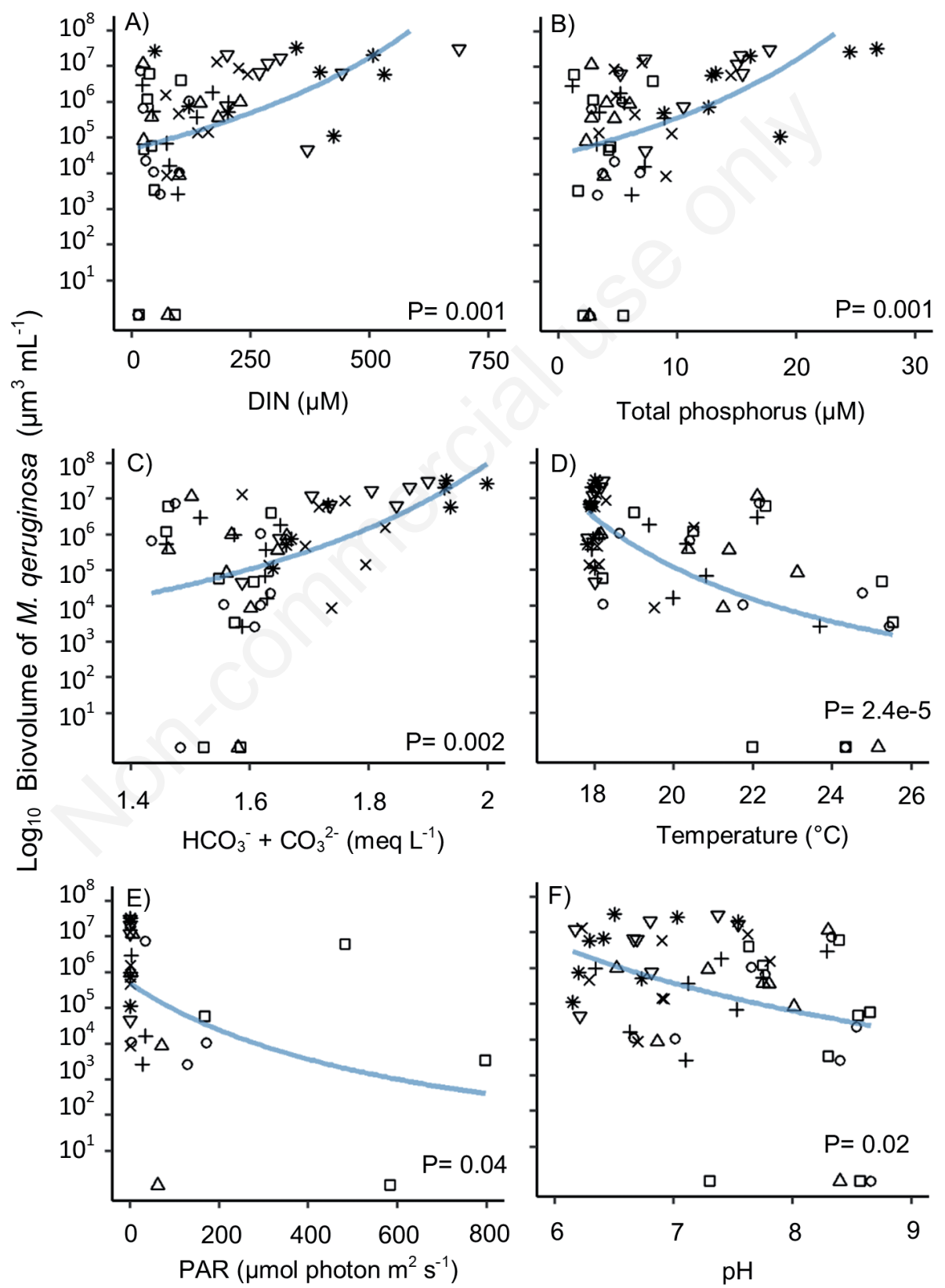

Fig. 7. Relationship of the biovolume of $M$. aeruginosa with different physical and chemical parameters: A) DIN. B) $\left.\mathrm{TP}^{\mathrm{C}} \mathrm{C}\right) \mathrm{HCO}_{3}{ }^{-}+$ $\mathrm{CO}_{3}{ }^{2-}$. D) Temperature. E) PAR. F) pH. Symbology refers to depth: square, $0 \mathrm{~m}$; circle ,5 m; triangle point up, $8 \mathrm{~m}$; plus, $10 \mathrm{~m}$; cross, $15 \mathrm{~m}$; triangle point down, $20 \mathrm{~m}$; star, $25 \mathrm{~m}$. 
dominance (with cyanobacterial blooms) has been reported in many eutrophic lakes and reservoirs around the world where anthropic activities - mostly the increasing number of farms in the proximity of these water bodies has boosted nutrient enrichment (Díaz-Pardo et al., 1998; Ramírez García et al., 2002; Vázquez et al., 2005; Beversdorf et al., 2013; Gkelis et al., 2014; Padedda et al., 2017; Qin et al., 2018; Almanza et al., 2019). Our results suggest that the current dominance of $M$. aeruginosa is related to the eutrophication of LAT resulting from human activities.

Eutrophication and cyanobacterial blooms cause trophic cascade effects in aquatic ecosystems (Filstrup et al., 2014), which usually result in low phytoplankton diversity (López-Archilla et al., 2004; Vázquez et al., 2005; Soares et al., 2009; Fernández et al., 2012). LAT showed no relationship between phytoplankton species richness $\left({ }^{\circ} D\right)$ and $M$. aeruginosa blooms since the highest ${ }^{\circ} D$ was observed in different seasons regardless of the location of M. aeruginosa blooms; similar results have been found in other eutrophic lakes and reservoirs (de Figueiredo et al., 2006; Chalar, 2009). These observations indicate that the eutrophic and hypertrophic conditions in LAT were suitable enough to support the coexistence of diverse phytoplankton species despite the presence of M. aeruginosa blooms. However, other diversity measures $\left({ }^{1} D\right.$ and $\left.{ }^{2} D\right)$ indicated an unequal proportion of the biovolume in the phytoplankton community since $M$. aeruginosa accounted for up to $95 \%$ of the total biovolume.

\section{Factors related to Microcystis aeruginosa blooms}

The trophic and environmental conditions of LAT in recent years were suitable for M. aeruginosa to become the dominant bloom-forming species. PCA and GLMs analyses revealed that $M$. aeruginosa blooms were associated with high DIN and TP concentrations and with low values of temperature and photosynthetically active radiation. These findings are consistent with other studies which also highlight nutrient enrichment, temperature, irradiance, $\mathrm{pH}$, and high water column stability as the key drivers of the dominance and blooms of cyanobacteria (Reynolds, 1987; Dokulil and Teubner, 2000; Paerl, 2008; O'Neil et al., 2012; Gobler et al., 2016; Wurtsbaugh et al., 2019).

Phosphorus $(\mathrm{P})$ and nitrogen $(\mathrm{N})$ are limiting nutrients that regulate phytoplankton assemblages; although $\mathrm{P}$ is considered as the main nutrient promoting cyanobacterial blooms, $\mathrm{N}$ is equally important (Reynolds, 1999; Smith, 2003). High $P$ and $N$ concentrations are clearly related with the dominance and blooms of different cyanobacteria in tropical and temperate lakes (Vázquez et al., 2005; Kosten et al., 2012; Gkelis et al., 2014; Almanza et al., 2019; Richardson et al., 2019). Experimental studies have corroborated these field observations, highlighting that $\mathrm{N}$ and $\mathrm{P}$ enrichment increases the growth rate in M. aerugi- nosa (Marinho and de Oliveira e Azevedo, 2007; Davis et al., 2009, 2010; Li et al., 2015). Besides, it has been mentioned that $\mathrm{P}$ and $\mathrm{N}$ concentrations above $5.6 \mu \mathrm{M}$ and $35.7 \mu \mathrm{M}$, respectively, promote blooms of this species (Reynolds, 1999; Zhao et al., 2019). Such nutrient requirements occurred in LAT in 2018 and 2019. Therefore, the increased $\mathrm{P}$ and $\mathrm{N}$ in LAT over the past years seem to play a crucial role in the dominance and bloom formation of $M$. aeruginosa.

The N:P molar ratio showed spatial and temporal variations with no significant relationship with $M$. aeruginosa. According to Smith (1983), an N:P ratio below 29:1 (observed on some occasions in LAT) tends to favor cyanobacterial dominance, especially by diazotrophic cyanobacteria, due to inorganic nitrogen limitation. However, M. aeruginosa is not a nitrogen-fixing species, and DIN limitation was not observed in LAT. In fact, the fluctuations in N:P ratio observed in this lake may result from the dynamics of M. aeruginosa blooms, similar to the Microcystis blooms in Lake Donghu, that were limited by the availability of $\mathrm{N}$ and P rather than low TN:TP ratios (Xie et al., 2003). Paerl et al. (2001) suggested that the N:P ratio may not be a deterministic factor in eutrophic or hypertrophic lakes because of the constant inputs of $\mathrm{N}$ and $\mathrm{P}$ that occasionally exceed the uptake capacity of algae, which in turn may explain the non-relationship of DIN:SRP and DIN:TP ratios with M. aeruginosa observed in LAT. Therefore, our data suggest that the dominance and blooms of M. aeruginosa are unrelated to the low $\mathrm{N}: \mathrm{P}$ ratio.

Temperature and PAR were the environmental factors related to M. aeruginosa blooms. Surface blooms were observed during autumn and winter at low water temperature $\left(18.8-21.4^{\circ} \mathrm{C}\right)$ and low PAR $(160$ - $480 \mu \mathrm{mol}$ photon $\mathrm{m}^{2} \mathrm{~s}^{-1}$ ) on the surface. Most studies have reported that high temperatures and strong stratification of the water column enhance surface blooms (Jacoby et al., 2000; Vázquez et al., 2005; Jöhnk et al., 2008; Kosten et al., 2012; Beversdorf et al., 2013; Deng et al., 2014). In Lake Chalchoapan, which is also a eutrophic, deep, warm monomictic lake in Mexico, M. aeruginosa was reported as the dominant species from May to December, with surface blooms events observed in summer at temperatures above $30{ }^{\circ} \mathrm{C}$ (Vázquez et al., 2005). However, it has also been reported that low temperatures during autumn and winter are suitable for the occurrence of surface blooms in temperate and tropical lakes (Almanza et al., 2019; Ninio et al., 2020), which is consistent with our results. In addition, it has been mentioned that high PAR ( $800-900 \mu \mathrm{mol}$ photon $\mathrm{m}^{2} \mathrm{~s}^{-1}$ ) causes photoinhibition in M. aeruginosa, affecting cell density and buoyancy, ultimately leading to the sinking of colonies (Visser et al., 1997; Chien et al., 2013; Yao et al., 2017), a phenomenon that may have influenced the occurrence of $M$. aeruginosa blooms in the surface. 
In the tropics, the occurrence of surface blooms of $M$. aeruginosa occurs mostly during the wet season, after rainfalls events, which carry nutrients into water bodies with surface runoff (Mowe et al., 2014). However, there was no clear evidence of increases in nutrient levels in LAT after the rainy season (June to October). Therefore, we could not associate blooms with rains and increased surface runoff. Indeed, seasonality is a critical driver of the variation in abundance and blooms of $M$. aeruginosa. However, the population dynamics of this cyanobacterium may vary among deep tropical lakes and may not display the common seasonal pattern observed in temperate regions, where the annual cycle involves the overwintering of benthic colonies in the bottom of the lake, population recovery during spring, blooming in summer, and sinking again in autumn (Walsby, 1981; Šejnohová and Maršálek, 2012). Moreover, the seasonal pattern in the biovolume of M. aeruginosa and its blooms in deep tropical lakes may be influenced by environmental and trophic conditions.

Populations of $M$. aeruginosa in concentrations that can be considered as blooms were also observed in the hypolimnion during spring and summer, under conditions of low PAR intensity ( $<1 \%$ of surface illumination), low DO concentration $\left(<0.5 \mathrm{mg} \mathrm{L}^{-1}\right)$, and low temperature $\left(<18^{\circ} \mathrm{C}\right)$. The presence of Microcystis in the hypolimnion could be related to the resting vegetative cells, which can persist in dark and anaerobic conditions for extended periods (Reynolds et al., 1981; Boström et al., 1989). Many studies have shown that colonies of $M$. aeruginosa, overwintering in the hypolimnion and surface sediments, can maintain a metabolic activity equivalent to a state of dormancy, under dark and anoxic conditions (Preston et al., 1980; Reynolds et al., 1981; Latour et al., 2004; Shi et al., 2007; Chen et al., 2018). It is possible that, in spring and summer, the Microcystis population found in the hypolimnion remained as an accumulation of resting vegetative colonies, which served as inoculum for the surface blooms observed in autumn and winter. This hypothesis is also supported by studies reporting the ability of $M$. aeruginosa to change its cell density and to regulate its buoyancy by gas vesicles, enabling migration along the water column (Reynolds, 1971; Reynolds and Walsby, 1975; Visser et al., 1997; Dokulil and Teubner, 2000; Hunter et al., 2008; Chien et al., 2013). Another possible factor related to the persistence of $M$. aeruginosa in the hypolimnion is the rise in mean hypolimnetic water temperature in the past ten years (from $17.2 \pm 0.1$ to $18 \pm 0.2^{\circ} \mathrm{C}$ ) (Caballero and Vázquez, 2020).

The present study did not assess the presence of cyanotoxins. However, level-1, level-2 and level-3 algal blooms were detected, indicating the potential presence of toxins in the lake (Chorus and Bartram, 1999; Global Water Research Coalition and Water Quality Research Australia, 2009; Newcombe et al., 2010). Therefore, spe- cial attention should be paid to assessing the toxicity of untreated lake water in the zone. Additionally, further research should evaluate the presence of toxic strains of $\mathrm{Mi}$ crocystis.

Monitoring the seasonal variation, dominance, and blooms of this species in LAT, as well as the environmental factors promoting its blooms, is needed to advance our understanding of cyanobacterial blooms in Mexican inland water bodies, particularly those showing signs of eutrophication. The conversion of forest to farmland in areas surrounding the lake appears to be the root cause of these bloom events. The establishment of a forest buffer zone around the lake will likely contribute to mitigate the impact of changes in land use and to reduce the magnitude and frequency of cyanobacterial blooms.

\section{CONCLUSIONS}

The trophic status of LAT appears to be aggravated by the conversion of forest areas into farmland in the areas surrounding the lake shifting from mesotrophic-eutrophic to eutrophic-hypertrophic. Thus, eutrophication may be the primary driver of cyanobacterial dominance in the phytoplankton community and cyanobacterial bloom events in this lake. The population dynamics of $M$. aeruginosa followed a seasonal pattern, and its blooms were mainly related to temperature, PAR, DIN and TP. The $M i$ crocystis population located in the hypolimnion during spring and summer suggests that the surface blooms in autumn and winter were originated from such hypolimnetic populations, which may have persisted as resting vegetative colonies.

\section{ACKNOWLEDGMENTS}

This research was funded by the National Autonomous University of Mexico (UNAM) though projects DGAPA-PAPIIT-IN100717, and DGAPA-PAPIITIN101513, and from Instituto de Ecología A. C. (Project 902-11-280). Authors acknowledge the technical support in laboratory analyses from Ariadna Martínez and Daniela Cela. Eloy Montero acknowledges the National Council for Science and Technology of Mexico (CONACYT) for the PhD scholarship (CVU 612333). María Elena Sánchez-Salazar edited the English manuscript.

\section{AUTHORSHIP}

Eloy Montero: Conceptualization, investigation, data analysis, writing the first draft. Gabriela Vázquez: Conceptualization, investigation, data analysis, reviewing, and editing article. Margarita Caballero: Conceptualization, investigation, data analysis, reviewing, and editing article. 
Mario E. Favila: Data analysis, reviewing, and editing article. Fernando Martínez-Jerónimo: Data analysis, reviewing, and editing article. All authors approved the final version of the manuscript and agreed to be accountable for all aspects of the work.

\section{REFERENCES}

Alcántara I, Piccini C, Segura AM, Deus S, González C, Martínez de la Escalera G, Kruk C, 2018. Improved biovolume estimation of Microcystis aeruginosa colonies: A statistical approach. J. Microbiol. Methods 151:20-27.

Alcocer J, Kato E, Robles E, Vilaclara G, 1998. Estudio preliminar del efecto del dragado sobre el estado trófico del lago viejo de Chapultepec. Rev. Int. Contam. Ambient. 4:43-56.

Almanza V, Pedreros P, Dail Laughinghouse H, Félez J, Parra O, Azócar M, Urrutia R, 2019. Association between trophic state, watershed use, and blooms of cyanobacteria in southcentral Chile. Limnologica 75:30-41.

Arzate-Cárdenas MA, Olvera-Ramírez R, Martínez-Jerónimo F, 2010. Microcystis toxigenic strains in urban lakes: a case of study in Mexico City. Ecotoxicology 19:1157-1165.

APHA, 1998. Standard Methods for the Examination of Water and Wastewater. 20th Edition. American Public Health Association, Washington, D.C.

Beversdorf LJ, Miller TR, McMahon KD, 2013. The role of nitrogen fixation in cyanobacterial bloom toxicity in a temperate, eutrophic lake. PLoS One 8:e56103.

Boström B, Pettersson AK, Ahlgren I, 1989. Seasonal dynamics of a cyanobacteria-dominated microbial community in surface sediments of a shallow, eutrophic lake. Aquat. Sci. 51:153-178.

Bourrelly P, 1968. Les Algues d'eau douce : initiation à la systématique. Tome II, $\mathrm{p}$ Les Algues jaunes et brunes. Chrysophycées, Phéophycées, Xanthophycées et Diatomées. Editions N. Boubée \& Cie, Paris.

Brunberg A-K, Blomqvist P, 2003. Recruitment of Microcystis (Cyanophyceae) from lake sediments: the importance of littoral inocula. J. Phycol. 39:58-63.

Caballero M, Vázquez G, 2020. Mixing patterns and deep chlorophyll a maxima in an eutrophic tropical lake in western Mexico. Hydrobiologia 847:4161-4176.

Caballero M, Vázquez G, Ortega B, Favila ME, Lozano-García S, 2016. Responses to a warming trend and "El Niño" events in a tropical lake in western Mexico. Aquat. Sci. 78:591-604.

Carey CC, Ibelings BW, Hoffmann EP, Hamilton DP, Brookes JD, 2012. Eco-physiological adaptations that favour freshwater cyanobacteria in a changing climate. Water Res. 46:1394-1407.

Carlson RE, 1977. A trophic state index for lakes. Limnol. Oceanogr. 22:361-369.

Carlson RE, 2007. Estimating trophic state. LakeLine 27:2528.

Chalar G, 2009. The use of phytoplankton patterns of diversity for algal bloom management. Limnologica 39:200-208.

Chao A, Chiu C-H, Jost L, 2014. Unifying species diversity, phylogenetic diversity, functional diversity, and related similarity and differentiation measures through Hill numbers. Annu. Rev. Ecol. Evol. Syst. 45:297-324.
Chen X, Huang Y, Chen G, Li P, Shen Y, Davis TW, 2018. The secretion of organics by living Microcystis under the dark/anoxic conditions and its enhancing effect on nitrate removal. Chemosphere 196:280-287.

Chien YC, Wu SC, Chen WC, Chou CC, 2013. Model simulation of diurnal vertical migration patterns of different-sized colonies of Microcystis employing a particle trajectory approach. Environ. Eng. Sci. 30:179-186.

Chorus I, Bartram J, 1999. Toxic Cyanobacteria in Water: A Guide to Their Public Health Consequences, Monitoring and Management. St Edmundsbury Press, Bury St Edmunds: 203 pp.

Davis T, Harke M, Marcoval M, Goleski J, Orano-Dawson C, Berry D, Gobler CJ, 2010. Effects of nitrogenous compounds and phosphorus on the growth of toxic and non-toxic strains of Microcystis during cyanobacterial blooms. Aquat. Microb. Ecol. 61:149-162.

Davis TW, Berry DL, Boyer GL, Gobler CJ, 2009. The effects of temperature and nutrients on the growth and dynamics of toxic and non-toxic strains of Microcystis during cyanobacteria blooms. Harmful Algae 8:715-725.

Deng J, Qin B, Paerl HW, Zhang Y, Ma J, Chen Y, 2014. Earlier and warmer springs increase cyanobacterial (Microcystis spp.) blooms in subtropical Lake Taihu, China. Freshw. Biol. 59:1076-1085.

Díaz-Pardo E, Vázquez G, López-López E, 1998. The phytoplankton community as a bioindicator of health conditions of Atezca Lake, Mexico. Aquat. Ecosyst. Health 1:257-266.

Dokulil MT, Teubner K, 2000. Cyanobacterial dominance in lakes. Hydrobiologia 438:1-12.

Dunn PK, Smyth GK, 2018. Chapter 11: Positive continuous data: gamma and inverse gaussian GLMs, p. 425-456. In: P.K. Dunn and G.K. Smyth (eds.), Generalized linear models with examples in R. Springer New York.

Edwin W, Kardinaal A, Visser PM, 2005. Dynamics of Cyanobacterial Toxins, p. 41-63. In: Huisman J, HCP Matthijs, and PM Visser (eds.), Harmful cyanobacteria. Springer Netherlands.

Feinsinger P, 2001. Designing Field Studies for Biodiversity Conservation. Island Press, Washington, D.C: 138 pp.

Fernández C, Parodi ER, Cáceres EJ, 2012. Phytoplankton structure and diversity in the eutrophic-hypereutrophic reservoir Paso de las Piedras, Argentina. Limnology 13:13-25.

Figueiredo DR de, Reboleira ASSP, Antunes SC, Abrantes N, Azeiteiro U, Gonçalves F, Pereira MJ, 2006. The effect of environmental parameters and cyanobacterial blooms on phytoplankton dynamics of a Portuguese temperate Lake. Hydrobiologia 568:145-157.

Filstrup CT, Hillebrand H, Heathcote AJ, Harpole WS, Downing JA, 2014. Cyanobacteria dominance influences resource use efficiency and community turnover in phytoplankton and zooplankton communities. Ecol. Lett. 17:464-474.

Frias HV, Mendes MA, Cardozo KHM, Carvalho VM, Tomazela D, Colepicolo P, Pinto E, 2006. Use of electrospray tandem mass spectrometry for identification of microcystins during a cyanobacterial bloom event. Biochem. Biophys. Res. Commun. 344:741-746.

Gkelis S, Papadimitriou T, Zaoutsos N, Leonardos I, 2014. Anthropogenic and climate-induced change favors toxic cyanobacteria blooms: Evidence from monitoring a highly 
eutrophic, urban Mediterranean lake. Harmful Algae 39:322 333.

Global Water Research Coalition, Water Quality Research Australia, 2009. International Guidance Manual for the Management of Toxic Cyanobacteria. Available from https://www.waterra.com.au/cyanobacteria-manual/PDF/ GWRCGuidanceManualLevel1.pdf

Gobler CJ, Burkholder JM, Davis TW, Harke MJ, Johengen T, Stow CA, Waal DB Van de, 2016. The dual role of nitrogen supply in controlling the growth and toxicity of cyanobacterial blooms. Harmful Algae 54:87-97.

Haande S, Ballot A, Rohrlack T, Fastner J, Wiedner C, Edvardsen B, 2007. Diversity of Microcystis aeruginosa isolates (Chroococcales, Cyanobacteria) from East-African water bodies. Arch. Microbiol. 188:15-25.

Hernández-Morales R, Ortega MR, Sánchez JD, Alvarado R, Aguilera MS, 2011. Distribución estacional del fitoplancton en un lago cálido monomíctico en Michoacán, México. Biológicas 13:21-28.

Hillebrand H, Dürselen C-D, Kirschtel D, Pollingher U, Zohary T, 1999. Biovolume calculation for pelagic and benthic microalgae. J. Phycol. 35:403-424.

Hsieh TC, Ma KH, Chao A, 2016. iNEXT: an R package for rarefaction and extrapolation of species diversity (Hill numbers). Methods Ecol. Evol. 7:1451-1456.

Huisman J, Sharples J, Stroom JM, Visser PM, Kardinaal WEA, Verspagen JMH, Sommeijer B, 2004. Changes in turbulent mixing shift competition for light between phytoplankton species. Ecology 85:2960-2970.

Huisman J, Codd GA, Paerl HW, Ibelings BW, Verspagen JMH, Visser PM, 2018. Cyanobacterial blooms. Nat. Rev. Microbiol. 16:471-483.

Hunter PD, Tyler AN, Willby NJ, Gilvear DJ, 2008. The spatial dynamics of vertical migration by Microcystis aeruginosa in a eutrophic shallow lake: a case study using high spatial resolution time-series airborne remote sensing. Limnol. Oceanogr. 53:2391-2406.

Ibelings BW, Vonk M, Los HFJ, Molen DT van der, Mooij WM, 2003. Fuzzy modeling of cyanobacterial surface waterblooms: validation with NOAA-AVHRR satellite images. Ecol. Appl. 13:1456-1472.

Instituto Nacional de Estadística y Geografía, 2016. Conjunto de datos vectoriales de uso del suelo y vegetación. Available from: https://www.inegi.org.mx/app/biblioteca/ficha.html? upc $=889463173359$

Jacoby JM, Collier DC, Welch EB, Hardy FJ, Crayton M, 2000. Environmental factors associated with a toxic bloom of Microcystis aeruginosa. Can. J. Fish. Aquat. Sci. 57:231-240.

Jöhnk KD, Huisman JEF, Sharples J, Sommeijer BEN, Visser PM, Stroom JM, 2008. Summer heatwaves promote blooms of harmful cyanobacteria. Glob. Chang. Biol. 14:495-512.

Jost L, 2007. Partitioning diversity into independent alpha and beta components. Ecology 88:2427-2439.

Jost L, DeVries P, Walla T, Greeney H, Chao A, Ricotta C, 2010. Partitioning diversity for conservation analyses. Divers. Distrib. 16:65-76.

Kalff J, 2002. Limnology: Inland Water Ecosystems. Prentice Hall, New Jersey: 148 pp.

Komárek J, 2008. Cyanoprokaryota. Teil 1 / Part 1: Chroococcales. Springer Spektrum.
Komárek J, Anagnostidis K, 2007. Süßwasserflora von Mitteleuropa, Bd. 19/2: Cyanoprokaryota. Bd. 2 / Part 2: Oscillatoriales. Springer Spektrum.

Kosten S, Huszar VLM, Bécares E, Costa LS, Donk E van, Hansson L-A, Jeppesen E, Kruk C, Lacerot G, Mazzeo N, Meester L De, Moss B, et al., 2012. Warmer climates boost cyanobacterial dominance in shallow lakes. Glob. Chang. Biol. 18:118-126.

Krammer K, Lange-Bertalot H, 1997. Süßwasserflora von Mitteleuropa, Bd. 02/2: Bacillariophyceae. Teil 2: Bacillariaceae, Epithemiaceae, Surirellaceae. Springer Spektrum.

Krammer K, Lange-Bertalot H, 1999. Süßwasserflora von Mitteleuropa, Bd. 02/1: Bacillariophyceae, 1. Teil: Naviculaceae, A: Text; B: Tafeln. Springer Spektrum.

Krammer K, Lange-Bertalot H, 2000. Bacillariophyceae. Teil 3: Centrales, Fragilariaceae, Eunotiaceae. Springer Spektrum.

Latour D, Sabido O, Salencon MJ, Giraudet H, 2004. Dynamics and metabolic activity of the benthic cyanobacterium $\mathrm{Mi}$ crocystis aeruginosa in the Grangent reservoir (France). J. Plankton Res. 27:716-726.

Lee RE, 2008. Cyanobacteria, p. 33-80. In: R.E. lee (ed.), Phycology. Cambridge University Press.

Li J, Wang Z, Cao X, Wang Z, Zheng Z, 2015. Effect of orthophosphate and bioavailability of dissolved organic phosphorous compounds to typically harmful cyanobacterium Microcystis aeruginosa. Mar. Pollut. Bull. 92:52-58.

López-Archilla AI, Moreira D, López-García P, Guerrero C, 2004. Phytoplankton diversity and cyanobacterial dominance in a hypereutrophic shallow lake with biologically produced alkaline $\mathrm{pH}$. Extremophiles 8:109-115.

Lund JWG, Kipling C, Cren ED Le, 1958. The inverted microscope method of estimating algal numbers and the statistical basis of estimations by counting. Hydrobiologia 11:143170.

Marinho MM, Oliveira e Azevedo SMF de, 2007. Influence of N/P ratio on competitive abilities for nitrogen and phosphorus by Microcystis aeruginosa and Aulacoseira distans. Aquat. Ecol. 41:525-533.

McCune B, Grace JB, 2002. Analysis of ecological communities. Gleneden Beach (OR): MjM Software Design.

Meeks JC, 1974. Chlorophylls, p. 161 - 175. In: W.D.P. Stewart (ed.), Algal physiology and biochemistry. Blackwell Scientific Publications.

Moestrup Ø, Calado A, 2018. Süßwasserflora von Mitteleuropa, Bd. 6 - Freshwater Flora of Central Europe, Vol. 6: Dinophyceae. Springer Spektrum.

Mowe MAD, Mitrovic SM, Lim RP, Furey A, Yeo DCJ, 2014. Tropical cyanobacterial blooms: a review of prevalence, problem taxa, toxins and influencing environmental factors. J. Limnol. 74:205-224.

Newcombe G, House J, Ho L, Baker P, Burch M, 2010. Management strategies for cyanobacteria (blue-green algae): a guide for water utilities. Research report 74. Water Quality Research Australia (WQRA). Available from https://www.waterra.com.au/publications/documentsearch/?download $=106$

Ninio S, Lupu A, Viner-Mozzini Y, Zohary T, Sukenik A, 2020. Multiannual variations in Microcystis bloom episodes Temperature drives shift in species composition. Harmful Algae 92:101710. 
O’Neil JM, Davis TW, Burford MA, Gobler CJ, 2012. The rise of harmful cyanobacteria blooms: the potential roles of eutrophication and climate change. Harmful Algae 14:313-334.

Oliver RL, Ganf GG, 2002. Freshwater Blooms, p. 149-194. In: B.A. Whitton and M. Potts (eds.), The ecology of cyanobacteria: their diversity in space and time. Springer Netherlands.

Padedda BM, Sechi N, Lai GG, Mariani MA, Pulina S, Sarria M, Satta CT, Virdis T, Buscarinu P, Lugliè A, 2017. Consequences of eutrophication in the management of water resources in Mediterranean reservoirs: A case study of Lake Cedrino (Sardinia, Italy). Glob. Ecol. Conserv. 12:21-35.

Paerl H, 2008. Nutrient and other environmental controls of harmful cyanobacterial blooms along the freshwater-marine continuum, p. 217-237. In: H.K. Hudnell (ed.), Cyanobacterial harmful algal blooms: state of the science and research needs. Springer New York.

Paerl HW, Fulton RS, Moisander PH, Dyble J, 2001. Harmful freshwater algal blooms, with an emphasis on cyanobacteria. Sci. World J. 1:139109.

Paerl HW, Paul VJ, 2012. Climate change: Links to global expansion of harmful cyanobacteria. Water Res. 46:1349-1363.

Pineda-Mendoza RM, Olvera-Ramírez R, Martínez-Jerónimo F, 2012. Microcystins produced by filamentous cianobacteria in urban lakes. A case study in Mexico City. Hidrobiológica 22:290-298.

Planas D, Paquet S, 2016. Importance of climate change-physical forcing on the increase of cyanobacterial blooms in a small, stratified lake. J. Limnol. 75:201-2014.

Preston T, Stewart W, Reynolds C, 1980. Bloom-forming cyanobaterium Microcystis aeruginosa overwinters on sediment surface. Nature 288:365-367.

Puddick J, Prinsep MR, Wood SA, Cary SC, Hamilton DP, Holland PT, 2015. Further characterization of glycine-containing microcystins from the McMurdo dry Valleys of Antarctica. Toxins 7:493-515.

Qin B, Yang G, Ma J, Wu T, Li W, Liu L, Deng J, Zhou J, 2018. Spatiotemporal changes of cyanobacterial bloom in large shallow eutrophic Lake Taihu, China. Front. Microbiol. 9:451.

R Core Team, 2019. R: a language and environment for statistical computing. R Foundation for Statistical Computing, Vienna, Austria. Available from: http://www.R-project.org

Ramírez García P, Nandini S, Sarma SSS, Robles Valderrama E, Cuesta I, Hurtado MD, 2002. Seasonal variations of zooplankton abundance in the freshwater reservoir Valle de Bravo (Mexico). Hydrobiologia 467:99-108.

Reynolds CS, 1971. The ecology of the planktonic blue-green algae in the North Shropshire meres. Fld. Stud. 3:409-432.

Reynolds CS, Walsby AE, 1975. Water blooms. Biol. Rev. 50:437-481.

Reynolds CS, 1987. Cyanobacterial Water-Blooms. Adv. Bot. Res. 13:67-143.

Reynolds CS, 1999. Non-determinism to Probability, or N : P in the community ecology of phytoplankton. Arch. für Hydrobiol. 146:23-35.

Reynolds CS, Jaworski GHM, Cmiech HA, Leedale GF, Lund JWG, 1981. On the annual cycle of the blue-green alga $M i$ crocystis aeruginosa Kütz. Emend. Elenkin. Philos. Trans. R. Soc. London. B, Biol. Sci. 293:419-477.

Richardson J, Feuchtmayr H, Miller C, Hunter PD, Maberly SC, Carvalho L, 2019. Response of cyanobacteria and phyto- plankton abundance to warming, extreme rainfall events and nutrient enrichment. Glob. Chang. Biol. 25:3365-3380.

Šejnohová L, Maršálek B, 2012. Microcystis, p. 195-228. In: B.A. Whitton (ed.), Ecology of cyanobacteria II: their diversity in space and time. Springer Netherlands.

Servicio Nacional Mateorológico (SNM), 2020. Información estadística climatológica. Available from: https://smn.conagua. gob.mx/es/climatologia/informacion-climatologica/informacion-estadistica-climatologica

Shi XL, Kong FX, Yu Y, Yang Z, 2007. Survival of Microcystis aeruginosa and Scenedesmus obliquus under dark anaerobic conditions. Mar. Freshwater Res. 58:634-639.

Smayda TJ, 1997. What is a bloom? A commentary. Limnol. Oceanogr. 42:1132-1136.

Smith VH, 1983. Low nitrogen to phosphorus ratios favor dominance by blue-green algae in lake phytoplankton. Science 221:669-671.

Smith VH, 2003. Eutrophication of freshwater and coastal marine ecosystems a global problem. Environ. Sci. Pollut. Res. 10:126-139.

Soares M, de A Rocha MI, Marinho MM, Azevedo SMFO, Branco CWC, Huszar MVL, 2009. Changes in species composition during annual cyanobacterial dominance in a tropical reservoir: physical factors, nutrients and grazing effects. Aquat. Microb. Ecol. 57:137-149.

Sun J, Liu D, 2003. Geometric models for calculating cell biovolume and surface area for phytoplankton. J. Plankton Res. 25:1331-1346.

Vasconcelos V, Martins A, Vale M, Antunes A, Azevedo J, Welker M, Lopez O, Montejano G, 2010. First report on the occurrence of microcystins in planktonic cyanobacteria from Central Mexico. Toxicon 56:425-431.

Vázquez G, Jiménez S, Favila ME, Martínez A, 2005. Seasonal dynamics of the phytoplankton community and cyanobacterial dominance in a eutrophic crater lake in Los Tuxtlas, Mexico. Écoscience 12:485-493.

Visser PM, Ibelings BW, Mur LR, Walsby AE, 2005. The Ecophysiology of the Harmful Cyanobacterium Microcystis, $\mathrm{p}$. 109-142. In: J. Huisman, H.C.P. Matthijs, and P.M. Visser (eds.), Harmful cyanobacteria. Springer Netherlands.

Visser PM, Passarge J, Mur LR, 1997. Modelling vertical migration of the cyanobacterium Microcystis. Hydrobiologia 349:99-109.

Walsby AE, 1981. Cyanobacteria: Planktonic Gas-Vacuolate Forms, p.224-235. In: M.P. Starr, H. Stolp, H.G. Trüper, A. Balows, and H.G. Schlegel (eds.), The prokaryotes: a handbook on habitats, isolation, and identification of bacteria. Springer Berlin Heidelberg.

Wan L, Chen X, Deng Q, Yang L, Li X, Zhang J, Song C, Zhou Y, Cao X, 2019. Phosphorus strategy in bloom-forming cyanobacteria (Dolichospermum and Microcystis) and its role in their succession. Harmful Algae 84:46-55.

Wells ML, Trainer VL, Smayda TJ, Karlson BSO, Trick CG, Kudela RM, Ishikawa A, Bernard S, Wulff A, Anderson DM, Cochlan WP, 2015. Harmful algal blooms and climate change: Learning from the past and present to forecast the future. Harmful Algae 49:68-93.

Wetzel RG, 2001. Limnology. Lake and River Ecosystems. Academic Press, San Diego: 81 pp.

Wilkinson AA, Hondzo M, Guala M, 2020. Vertical hetero- 
geneities of cyanobacteria and microcystin concentrations in lakes using a seasonal In situ monitoring station. Glob. Ecol. Conserv. 21:e00838.

Winder M, Hunter DA, 2008. Temporal organization of phytoplankton communities linked to physical forcing. Oecologia 156:179-192.

Wurtsbaugh WA, Paerl HW, Dodds WK, 2019. Nutrients, eutrophication and harmful algal blooms along the freshwater to marine continuum. WIREs Water 6:e1373.

Xie L, Xie P, Li S, Tang H, Liu H, 2003. The low TN:TP ratio, a cause or a result of Microcystis blooms? Water Res. 37:2073-2080.

Yao B, Liu Q, Gao Y, Cao Z, 2017. Characterizing vertical migration of Microcystis aeruginosa and conditions for algal bloom development based on a light-driven migration model. Ecol. Res. 32:961-969.

Zhao CS, Shao NF, Yang ST, Ren H, Ge YR, Feng P, Dong BE, Zhao Y, 2019. Predicting cyanobacteria bloom occurrence in lakes and reservoirs before blooms occur. Sci. Total Environ. 670:837-848. 